\title{
Phacopid trilobites in post-Taghanic Givetian through Frasnian cephalopod limestones, Montagne Noire (France) and related areas (Thuringia, Morocco)
}

\author{
RaIMUnd FeIST \& GILBert Klapper
}

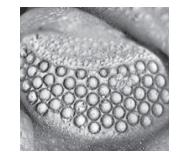

\begin{abstract}
This paper establishes the ranges of late Givetian and Frasnian phacopid trilobites with reference to the Frasnian conodont zonation. The ranges integrate both hitherto formally known and numerous new taxa that were recovered from outer shelf limestones primarily in the Montagne Noire (southern France) and incidentally in related areas; i.e. Thuringia and SE Morocco. Though considering twice the number of genera and species as previously known, the distribution of phacopids emphasises the generally admitted low diversity in the time interval between the Taghanic and Kellwasser crises. New evidence highlights the fact that diversity rates did not remain constant over the period but increased slightly in mid- and late Frasnian times. The currently proposed lower-middle Frasnian substage boundary at the base of the punctata Zone (FZ 5) is supported by two major innovations at the generic level. The investigated outer shelf phacopids are all characterised by reduced eyes with either a reduced visual surface or with forwardly positioned and diminutive eye lobes. In the systematic part the following taxa are presented: Cronierella gen. nov. with the new species: $C$. gallica, C. postera, C. expansa, C.? sp. nov. A; Occitanella gen. nov. with the new species: $O$. postinflexa, $O$. hexagonalis, and $O . ?$ sp. indeterminate; Chlupacops Feist, 2016 with the new species C. angularis, C. narbonnensis, C. clapassousensis, C. migrans, C. rectannulatus; Acutiphacops gen. nov. with the new species: A. tchrafinensis, A. medius; Acuticryphops prorotundus sp. nov.; Girardina gen. nov. with the new species: G. konradbartzschi, G. consimilis, and with G.? liopyga (Richter, 1863). • Key words: phacopid trilobites, late Givetian, Frasnian, conodont-based biostratigraphy, eye reduction, systematics.
\end{abstract}

Feist, R. \& Klapper, G. 2022. Phacopid trilobites in post-Taghanic Givetian through Frasnian cephalopod limestones, Montagne Noire (France) and related areas (Thuringia, Morocco). Bulletin of Geosciences 97(1), 1-32 (8 figures). Czech Geological Survey, Prague. ISSN 1214-1119. Manuscript received April 4, 2021; accepted in revised form September 24, 2021; published online November 20, 2021; issued January 23, 2022.

Raimund Feist, Institut des Sciences de l'Evolution, Laboratoire de Paléontologie, Université Montpellier, pl. E. Bataillon, F34095 Montpellier, France; raimund.feist@umontpellier.fr • Gilbert Klapper, Earth and Planetary Sciences, Northwestern University, Evanston, IL 60208, USA

The late Middle Devonian Taghanic crisis (House 1985, Zambito et al. 2012) severely affected the evolutionary history of trilobites. After the demise of four families and six subfamilies shortly before and during the late middle Givetian event interval (Aboussalam 2003), trilobites experienced the lowest diversity rates in the Devonian (Feist 1991, Chlupáč 1994, Lerosey-Aubril \& Feist 2012). In the Phacopidae this decline had already started at the end of the early Givetian when, from six genera with some 40 species present in the Rhenish Slate Mountains, Germany (Basse 1998, 2006), the only species that reached the middle Givetian were those questionably assigned to Hypsipariops such as H.? torleyi (Basse \& Lemke, 1996) and H.? batracheus (Whidborne, 1889) from the famous Lummaton shell-bed in southern England, as well as descendants of Chotecops, the koeneni group (Meischner 1965, Basse \& Lemke 1996). These taxa vanished at the Taghanic crisis. In eastern and midcontinent North
America "Phacops" iowensis and subspecies of the widespread Middle Devonian Eldredgeops rana were still present prior to the Taghanic Event, but only the latter survived the crisis (Eldredge 1972). Based on the paucity of phacopids in the interval between the end mid-Givetian Taghanic and the terminal Frasnian Kellwasser events, the generally low diversity trend was thought to affect likewise the Phacopidae with only a few innovations (Lerosey-Aubril \& Feist 2012). That view is revised here after discoveries of numerous new taxa mainly from the Montagne Noire that double the number of those hitherto known. Taking into account all formally recognized taxa these are listed according to their biostratigraphical occurrences (Fig. 1). Most of them are well constrained by associated conodont zonal markers and can be assigned to conodont zones (Fig. 1, bold lines). However, their occurrences might not range through the entire zone, or alternatively, their ranges might extend beyond a single 


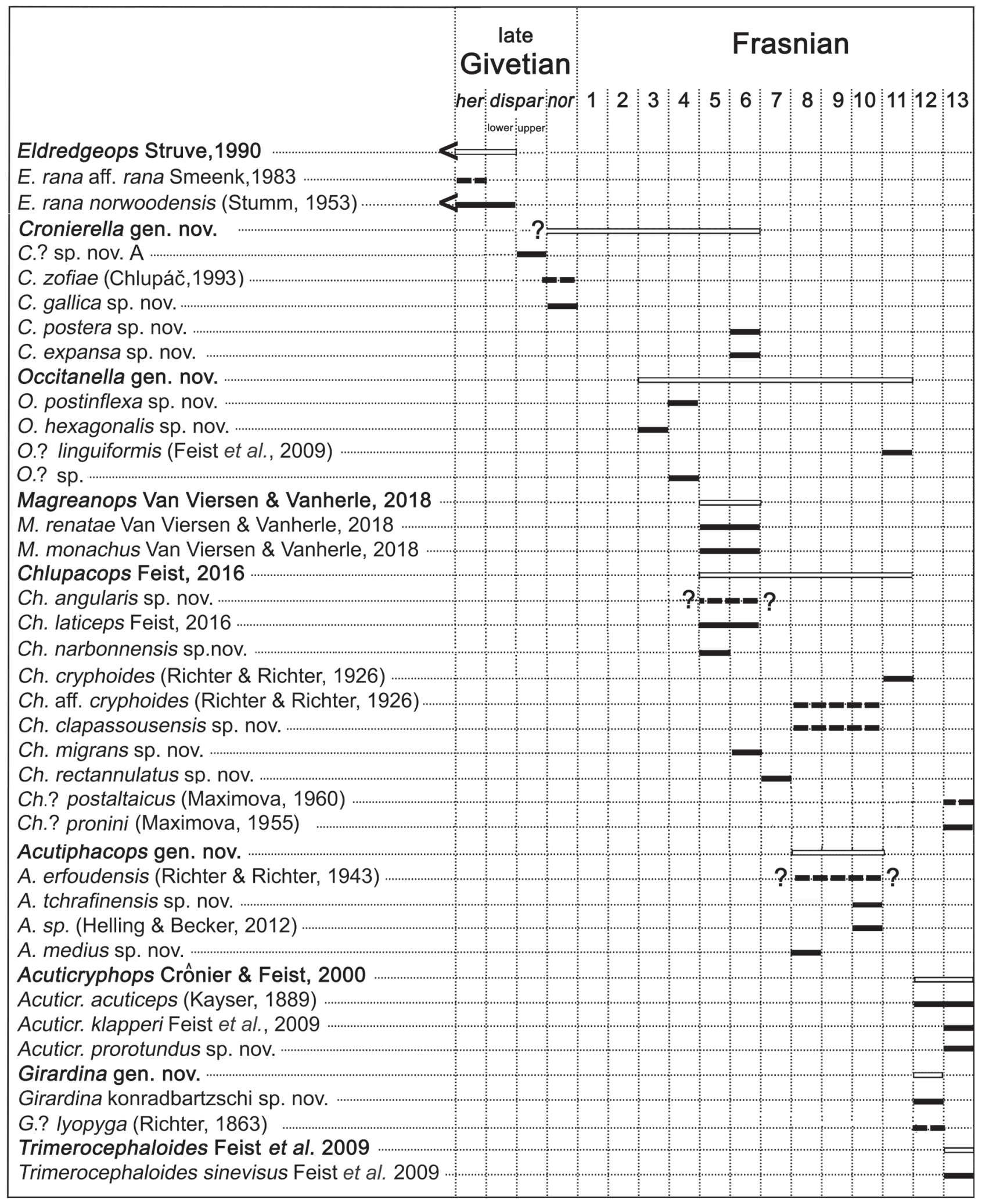

Figure 1. Range chart of late Givetian through Frasnian Phacopidae according to conodont biozonation (her - hermanni Zone; dispar - disparilis Zone; nor - norrisi Zone). Explanation: bold lines - known occurrences; empty lines - inferred occurrences; dashed lines - presumed ranges; question marks - possible extensions; arrows - extensions below upper Givetian. 
zone. In contrast, zonal assignment of other taxa remains undetermined when no significant conodonts were associated (Fig. 1, dashed lines); their biostratigraphical ranges according to the conodont zonation are tentative and need further investigation. Whereas seven out of nine genera from the considered time interval occur in at least two different palaeogeographic entities (Crônier \& François 2014), 55\% of the species are restricted to the Montagne Noire, virtually indicating a high degree of endemism but calling for further search in similar outer shelf sites of neighbouring regions.

\section{Biostratigraphy and location}

\section{Late Givetian occurrences}

Hitherto known post-event occurrences of phacopids in Variscan Europe in the late Givetian remained extremely scarce, restricted to two taxa of Eldredgeops rana affinity recognized in the southern Cantabrian Mountains (Smeenk 1983). In midcontinent North America only Eldredgeops rana norwoodensis persisted in the late Givetian (Hickerson 1997). In Australia a single phacopid cephalon from the late Givetian or possibly early Frasnian Mytton Formation in the Broken River region of North Queensland was described by Feist \& Talent (2000) as Phacops sp., but the poor preservation does not allow confident assignment. Stegemann (2005) described and figured the first late Givetian phacopid remains from Morocco that she assigned to unnamed new subspecies of Hypsipariops? torleyi. Though listed in the compendium of North African trilobites by Bault et al. (2021), the material needs revision taking into account the configuration of the intercalating ring that obviously differs from that of Hypsipariops and torleyi. In the Holy Cross Mountains, Chlupáč (1993) described Phacops (Chotecops) zofiae from the Givetian-

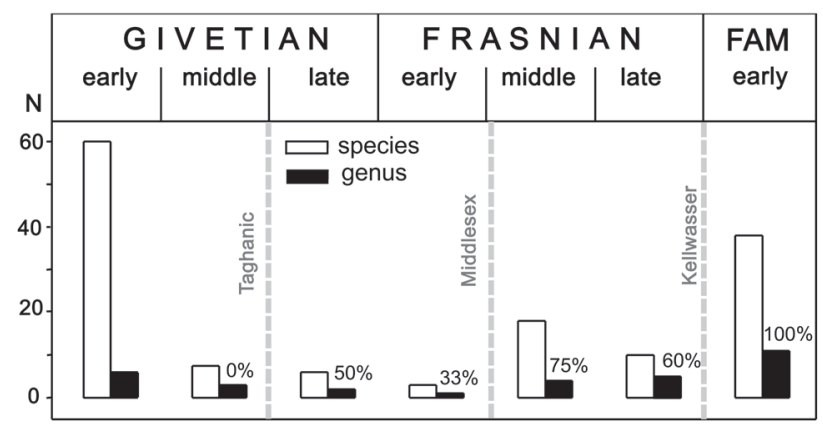

Figure 2. Diversity trends of phacopid species between early Givetian and early Famennian indicating the position of the Taghanic, Middlesex and Upper Kellwasser events (empty columns - number of species; bold columns - number of genera). Generic innovation rates are given in percentage of total number.
Frasnian boundary beds at Szydłówek, which we assign to the new genus Cronierella from the topmost Givetian and lower Frasnian. To date, only two genera (Eldredgeops and Cronierella) are recognized with confidence in the late Givetian. Among them, the appearance of Cronierella seems to constitute a slight recovery from the Taghanic crisis no earlier than at the end of the Givetian (Fig. 2). Though further new occurrences in Moroccan strata are expected (see Aboussalam \& Becker 2001 for presence of phacopids in the hermanni Zone at Bou Tchrafine), the rather poor record confirms the extremely low diversity with the probable extinction of Eldredgeops and a single innovation at the end of the Middle Devonian.

\section{Frasnian occurrences}

The paucity of phacopids that characterises the late Givetian was considered to persist into the early Frasnian where only a single phacopid was recovered from "Chemung" sandstones of New York (Eldredge 1972, p. 93), probably from the Ithaca Sandstone of FZ 2-3 age (Klapper \& Kirchgasser 2016). This taxon, referred to Eldredgeops rana rana by Eldredge, led to the assumption that Eldredgeops persisted into the Late Devonian (Crônier \& François 2014). However, besides the fact that this material was not located stratigraphically with precision, it was neither figured nor described. Thus its assignment remains doubtful and it is not considered here. Cronierella, though appearing just below the G-F boundary, has not yet been identified in early Frasnian strata but reappears in the middle Frasnian (FZ 6). The new genus Occitanella with two (three?) species from the Montagne Noire is the only taxon currently known in the early Frasnian. The substage has the same low innovation rate as that of the late Givetian. As such it confirms the lowest diversity for trilobites in general (e.g. for North African occurrences, Bault et al. 2021). In phacopids the curve of low diversity trends greatly changes when two genera, Chlupacops and Magreanops, appear at the base of the middle Frasnian (Feist et al. 2016, Van Viersen \& Vanherle 2018). Together with the reappearance of Cronierella and the appearance of the new genus Acutiphacops in the higher part of the substage, there are four genera with 18 species present in the middle Frasnian. However, among this relatively high number of taxa at the specific level, some cannot be precisely attributed to conodont zones (marked by dashed lines in Fig. 1) mainly because of the absence of significant conodont data. In some cases the presumed stratigraphical position remains doubtful (taxa marked with question in Fig. 1) and needs confirmation from new investigations. This concerns in particular the position of Acuticryphops erfoudensis that Richter \& Richter (1943) described from material collected by the Termiers 
in the 1930s in the surroundings of Erfoud (Tafilalt, SE Morocco). On the basis of its morphological proximity to Acutiphacops taxa from the late middle Frasnian of Bou Tchrafine a similar age attribution is tentatively presumed. Increase of diversity is corroborated in the late Frasnian where, in addition to the entry of two previously known genera, the new genus Girardina appears simultaneously in the Montagne Noire and in eastern Thuringia. Both Occitanella (?) and Chlupacops persist in the late Frasnian with a single species each. To the latter might be assigned with question two species from the Rudny Altai and from the eastern slope of the middle Urals: $C h$. ? postaltaicus Maximova, 1960 and Ch.? pronini Maximova, 1955 respectively. The biostratigraphical position of the latter species, occurring in the "Crickites Zone" according to Maximova (1955, p. 193), raises the question of whether an earliest Famennian ("post I $\delta$ ") age could be considered (Feist 2019). However, the species is said to be associated with the last scutelluids that became extinct at the terminal Frasnian Kellwasser crisis. Consequently, both Ch.? pronini as well as Ch.? aff. pronini (the latter being associated with postaltaicus) are probably of latest Frasnian age though no conodont control is available. To sum up, five genera with 10 species are present in the late Frasnian. The reversal from initially very low diversity rates to positive trends initiated in the midFrasnian is corroborated at the end of the stage (Fig. 2). The terminal Frasnian Kellwasser Event severely affected the Phacopidae as no lower rank taxon survived into the Famennian (McNamara \& Feist 2016). In sharp contrast the early Famennian recovery is characterised by high innovation rates when five new genera with some 38 species successively appear (Feist 2019).

The biostratigraphical significance of the Phacopidae in the Frasnian in terms of discriminating currently debated positions of substage boundaries may be partially important. Whereas the initial pulse of the Frasnes Event in the terminal Givetian norrisi Zone (Becker et al. 2020) coincides with the innovation of the Cronierella line, the exact position of the Givetian-Frasnian boundary cannot be discriminated as any innovation is currently unknown at the beginning of the Frasnian. By contrast, the base of FZ 5 (Middlesex transgression or punctata Event) is well marked by the concomitant innovation of Magreanops in the organodetrital inner-shelf realm and Chlupacops in the off-shore cephalopod realm. Allowing time-scaled correlation between the two realms the appearance of these phacopid biostratigraphical markers supports defining the middle Frasnian substage at the base of the punctata Zone (Fig. 2). By contrast, the start of the proposed late Frasnian substage with the semichatovae Event just slightly above the base of FZ 11 (see Conodont Zonation) is less well supported as only two species appear at this level. Major innovations in the
Phacopidae occur a little higher, when Acuticryphops and Girardina appear in FZ 12 and Trimerocephaloides in FZ 13.

\section{Frasnian conodont zones and events (G. Klapper)}

The thirteen-fold Frasnian conodont zonation (abbreviated as FZ) was established originally through the analysis of overlapping species ranges in six measured sections (Feist \& Klapper 1985, Klapper 1985) in the Montagne Noire (Klapper 1989). The ranges of all short-ranging conodont species, including those of Ancyrodella, Ancyrognathus and Ozarkodina, were used in developing the zonation in addition to those of Palmatolepis, the first occurrences of which define the majority of the bases of zones. As has been demonstrated in subsequent studies, the zonation is not confined to the Montagne Noire but has been tested and demonstrated to be widely applicable in Devonian tropical areas. These include among others, the Canning Basin of Western Australia (Klapper 2007, 2009), the Alberta Rockies and central Alberta subsurface, western Canada (McLean \& Klapper 1998), and the classic sections of western New York State (Kirchgasser 1994, Kralick 1994, Klapper \& Kirchgasser 2016). Because of its widespread application, Klapper \& Kirchgasser (2016) recommended a significant change in terminology from the Montagne Noire (MN) zonation to the Frasnian Zonation (FZ).

The Frasnian Zonation was integrated with graphic correlation through studies of sequences, for example the Timan Range of European Russia (Klapper et al. 1996), Luscar Mountain in the Alberta Rockies, the Hay and Trout river areas of southwestern Northwest Territories (Klapper 1997), the Moose River Basin, northern Ontario (Klapper et al. 2004), all in Canada, and western New York (Klapper et al. 1995, Klapper \& Kirchgasser 2016).

In the restudy of the Martenberg section in the Rhenish Slate Mountains, one of the key sections of the Frasnian Standard Zonation of Ziegler \& Sandberg (1990), the transitans through linguiformis zones were shown to correlate with FZ zones 4 through 13 (Klapper \& Becker 1999, text-fig. 1). The FZ 13 spans from the upper rhenana through linguiformis zones of the standard zonation, and thus because of its long span was subdivided into three subzones (Girard et al. 2005).

The Middle Devonian (late Givetian) zones shown in Figure 1 correspond to the usage of Klapper \& Johnson (in Johnson 1990), in ascending order: hermanni, lower and upper disparilis, and norrisi zones. Bold lines in this figure indicate joint occurrences of the zonal conodonts with the trilobites.

In regard to intra-Frasnian events, much discussed in recent Devonian literature, the base of FZ 5 (= punctata 


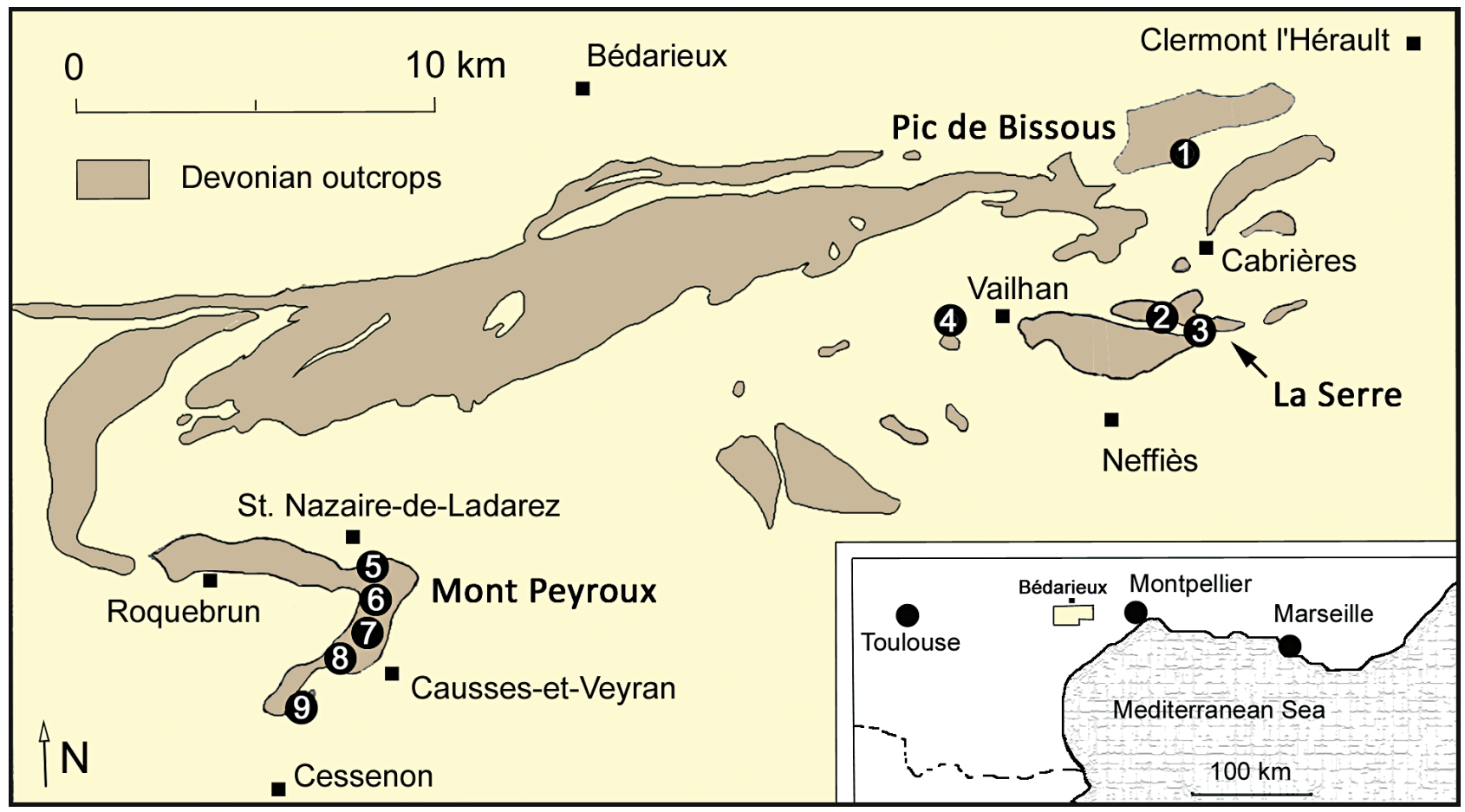

Figure 3. Location of conodont-dated phacopid sites in Devonian outcrops of southeastern Montagne Noire (1 - Pic de Bissous; 2 - Soureillé d'Izarne; 3 - La Serre; 4 - Combe Rolland; 5 - Col du Puech de la Suque; 6 - Clapassous; 7 - Mont Peyroux; 8 - Causses-et-Veyran; 9 - Coumiac). For locality register see text.

Zone of Ziegler \& Sandberg 1990) was thought to coincide with the Middlesex Event, one of the two main transgressions within the classic New York State Frasnian succession. The correlation of the base of the punctata Zone with the Middlesex Event in the Rhenish Slate Mountains and Polish sections (e.g. Pisarzowska et al. 2020) was based on using the FAD of Ancyrodella nodosa (=A. gigas form 1 of earlier literature) for that identification, rather than Palmatolepis punctata (shown in Pisarzowska et al. 2006, tabs 5,6) and as discussed in their 2020 paper (op. cit., p. 4). Ancyrodella nodosa as revised in Klapper \& Kirchgasser (2016, p. 537, tab. 2) occurs only a short interval below the base of FZ 5 in terms of graphic correlation; this means that its FAD is within the upper part of FZ 4 (= transitans Zone). Its illustrated occurrence in the upper $2 \mathrm{~cm}$ of the Middlesex at Eighteenmile Creek (Over et al. 2003, pp. 218, 219, pl. 1, fig. 5) is close below the entry of Palmatolepis punctata in the overlying basal Cashaqua Shale. The details of its lower range within the Middlesex (op. cit., fig. 2) are not given.

The major transgression within the New York Frasnian sequence begins at the base of the Rhinestreet Shale and was earlier taken as the second intra-Frasnian event (House 2002, p. 17 and references therein). However, Sandberg et al. (2002, p. 479) used the semichatovae transgression, which is based on the FAD of this species of Palmatolepis, as a signficant intra-Frasnian event. It seems now to be widely used. In the New York succession, the semichatovae FAD occurs in the higher part of the Rhinestreet at the Relyea Creek Horizon (Klapper \& Kirchgasser 2016, figs 5, 6, tabs 1,2) and is slightly less than one composite standard unit in graphic correlation above the base of FZ 11 .

\section{Location of occurrences}

Montagne Noire occurrences. - In the south-eastern Montagne Noire nine localities have yielded late Givetian and Frasnian phacopid trilobites (Fig. 3). Associated conodonts and conodont ranges in columnar sections were determined by G. Klapper. Locality register follows Klapper $(1989$, pp. 456, 457) and is supplemented herein. Coordinates are calculated from Google Earth mapping.

(1) Pic de Bissous, section VS-E, deep slope at $150 \mathrm{~m}$ southwest of the peak, at $2.3 \mathrm{~km}$ north of Cabrières, $43^{\circ} 35^{\prime} 49.19^{\prime \prime} \mathrm{N}, 3^{\circ} 21^{\prime} 16.68^{\prime \prime} \mathrm{E}$. Location and columnar diagram of the sequence is shown in Feist (1983, fig. 13), Feist \& Klapper (1985, figs 3, 5) and Klapper (1985, fig. 1). Phacopid occurrences in bed 49: Occitanella hexagonalis gen. and sp. nov., Frasnian Zone 3. 
(2) Soureillé d'Izarne section, southern flank of hill, at $2 \mathrm{~km} \mathrm{SW}$ of Cabrières, $300 \mathrm{~m} \mathrm{~N}$ of La Rouquette farm house, stop 10 in Feist (1983). Phacopid locality: 43 $33^{\prime}$ $29.09^{\prime \prime} \mathrm{N}, 3^{\circ} 21^{\prime} 02.32^{\prime \prime} \mathrm{E},=$ Acuticryphops prorotundus sp. nov.

(3) La Serre trenches A, A' and C, on the southern flank of the east-west oriented La Serre hill, south and south-east of the western summit 252 , at $2.2 \mathrm{~km}$ south of Cabrières. $\mathrm{A}, \mathrm{A}^{\prime}=43^{\circ} 33^{\prime} 24.43^{\prime \prime} \mathrm{N}, 3^{\circ} 21^{\prime} 20.06^{\prime \prime} \mathrm{E}, 500 \mathrm{~m}$ eastnortheast of La Rouquette farm house. Location and columnar diagrams are shown in Feist (1983, figs 19, $20)$, Feist \& Klapper (1985, figs 4, 5, 8, 9) and in Feist (2002, fig. 30b). Phacopid occurrences: bed A 102C, A'17 ("lumachelle à phacopidés" of Feist 1976, "Phacopsbed" of Feist 1983, 1985) = Cronierella gallica gen. and sp. nov., Givetian norrisi Zone; bed A 129 and A'42 = Cronierella expansa gen. and sp. nov., Frasnian Zone 6; bed A 133 = Cronierella postera gen. and sp. nov., Frasnian Zone 6; bed A'48 = Chlupacops migrans sp. nov., Frasnian Zone 6; A'60 = Chlupacops rectannulatus sp. nov., Frasnian Zone 7; A'71 = Acutiphacops medius gen. and sp. nov., Frasnian Zone 8. C $=43^{\circ} 33^{\prime} 21.77^{\prime \prime}$, $3^{\circ} 21^{\prime} 35.56^{\prime \prime} \mathrm{E}, 650 \mathrm{~m}$ east-northeast of La Rouquette farm house. Location and columnar diagrams are shown in House et al. (1985, fig. 12), Feist (1990, fig. 28; 2002, fig. 31). Phacopid occurrences: bed $13=$ Acuticryphops prorotundus sp. nov.

(4) Combe Rolland, road-section at $1.5 \mathrm{~km} \mathrm{~W}$ of Vailhan. Phacopid locality: $43^{\circ} 33^{\prime} 03.11^{\prime \prime} \mathrm{N}, 3^{\circ} 17^{\prime} 07.83^{\prime \prime} \mathrm{E}=$ Acuticryphops prorotundus sp. nov.

(5) Col du Puech de la Suque, CPS-E section, natural outcrops about $50 \mathrm{~m}$ east of the crest of hill 358 at $700 \mathrm{~m}$ SE of St Nazaire-de-Ladarez, $43^{\circ} 30^{\prime} 11.46^{\prime \prime} \mathrm{N}, 3^{\circ} 05^{\prime}$ $11.19^{\prime \prime}$ E. Location and columnar sections are shown in Feist (1983, figs 9, 10), Klapper (1985, fig. 2), Feist \& Klapper (1985, figs 2, 5), House et al. (1985, figs 1b, 2) Klapper et al. (1987, fig. 1) and Feist (2002, fig. 21). Phacopid occurrences in CPS-E: Occitanella postinflexa gen. and sp. nov., Chlupacops angularis sp. nov., Chlupacops narbonnensis sp. nov.

(6) Clapassous, western slope of Puech de la Suque hill, $300 \mathrm{~m}$ SSE of CPS-E section, at $1 \mathrm{~km}$ SE of St Nazaire-deLadarez, $43^{\circ} 30^{\prime} 03.53^{\prime \prime} \mathrm{N}, 3^{\circ} 05^{\prime} 19.91^{\prime \prime} \mathrm{E}=$ Chlupacops clapassousensis sp. nov., Ch. migrans sp. nov.

(7) Mont Peyroux, Col des Tribes Sud section (CT-S), eastern slope at $200 \mathrm{~m}$ E of summit, at $2 \mathrm{~km} \mathrm{SE}$ of St Nazaire-de-Ladarez, $43^{\circ} 29^{\prime} 24.72^{\prime \prime} \mathrm{N}, 3^{\circ} 06^{\prime} 22.07^{\prime \prime}$ E. Location and columnar sections are shown in Dartiguenave (1999, figs 2, 6, 9) and Aboussalam (2003, fig. 30). Phacopid occurrences: Cronierella? sp. nov. A, Occitanella? sp.

(8) Causses-et-Veyran, $500 \mathrm{~m} \mathrm{NW}$ of village, at about $100 \mathrm{~m} \mathrm{NE}$ of section CV-S (Feist 1990, figs 10-12), $43^{\circ} 28^{\prime} 45.38^{\prime \prime} \mathrm{N}, 3^{\circ} 04^{\prime} 48.64^{\prime \prime} \mathrm{E}=$ Acuticryphops acuticeps (Kayser, 1889), Girardina consimilis gen. and sp. nov.

(9) Coumiac, abandoned marble quarry at $2 \mathrm{~km} \mathrm{~N}$ of Cessenon, upper quarry at $200 \mathrm{~m}$ west of "Les Granges" farm house, $43^{\circ} 28^{\prime} 13.86^{\prime \prime} \mathrm{N}, 3^{\circ} 03^{\prime} 35.38^{\prime \prime}$ E. Location and columnar sections are shown in Feist (1983, figs 7, 11), Feist \& Klapper (1985, figs 2, 5), House et al. (1985, figs 1a, 9), Becker et al. (1989, figs 1-3), Feist (1990, figs 17-21). Phacopid occurrence: Acuticryphops acuticeps (Kayser, 1889).

Moroccan occurrence. - Bou Tchrafine at $9 \mathrm{~km} \mathrm{SE} \mathrm{of}$ Erfoud, Tafilalt, SE Morocco, $31^{\circ} 22^{\prime} 34.53^{\prime \prime} \mathrm{N}, 4^{\circ} 09^{\prime}$ 59.44" E. Location and columnar sections are shown in Buggisch \& Clausen (1972, fig. 2), Bultynck \& Walliser (2000, figs 1, 8), Becker \& House (2000, fig. 1). Phacopid occurrences: Acutiphacops tchrafinensis gen. and sp. nov., Acutiphacops erfoudensis (Richter \& Richter, 1943)

Thuringian occurrence. - Abandoned Kahlleite quarry at $6 \mathrm{~km}$ NE of Schleiz, $50^{\circ} 37^{\prime} 40.90^{\prime \prime} \mathrm{N}, 11^{\circ} 50^{\prime} 51.46^{\prime \prime} \mathrm{E}$. Location and columnar section shown in Gereke (2007, figs 29, 35). Phacopid occurrences: Acuticryphops acuticeps (Kayser, 1889), Girardina konradbartzschi gen. and sp. nov. Bohlen section at $1.5 \mathrm{~km} \mathrm{~S}$ of Saalfeld, $50^{\circ} 37^{\prime} 60^{\prime \prime} \mathrm{N}, 11^{\circ} 22^{\prime} 52^{\prime \prime} \mathrm{E}$. Location and columnar section shown in Pfeiffer (1954, tab. 1). Phacopid occurrences: Chlupacops cryphoides (Richter \& Richter, 1926); Laasen (Probstzella), Köppchen, 259 m NW Laasen (fide Pfeiffer 1959): Girardina? liopyga (Richter, 1863).

\section{Palaeontology (R. Feist)}

\section{Trends in eye reduction}

One of the common morphological features of Silurian through Middle Devonian Phacopidae is the development of large kidney-shaped eyes with a great number of lenses arranged in vertical rows. Phacopids of this kind occur in various types of organodetrital facies of shallow neritic environments but also in deeper, mostly micritic limestone facies where they lived on the muddy sea floor within the photic zone (Chlupáč 1977). Such phacopids were markedly restricted in their diversity in the late Givetian where only representatives of Eldredgeops 
survived the Taghanic crisis and occur in midcontinent North America and in the Cantabrian Mountains. The so-far unique presence of large-eyed phacopids in the Frasnian was recently brought to light by Van Viersen \& Vanherle (2018) in early mid-Frasnian lateral facies of sea mounds in the Ardennes. This important discovery bears witness that the ancestral configuration of a largesized eye complex must have persisted in shallow neritic environments allowing their epibenthic activity in photic bottom habitats. The advent of Cronierella in the terminal Givetian marks the first hint of eye-reduction in the largeeyed configuration, when the dorsoventral height of the visual field diminishes and the number of lenses in vertical rows reduces to four lenses. The posterior end of the eye lobe is markedly reduced in height whereas its exsagital length remains unchanged.

Eye reduction leading to forward shift and diminishing in size of the eye lobe became a general phenomenon in Frasnian Phacopidae. When similar cases of eye reduction occur in some older taxa from the Lower and Middle Devonian (e.g. Eocryphops, Struveaspis, Prokops) they were considered to be environmentally controlled, as these forms preferentially inhabited poorly consolidated, quiet, muddy substrates in deeper water (Chlupáč 1977 and other authors). Their occurrences are sporadic and recurrent in various time intervals and their mode of regression of the visual surface ("cryptophthalmus pattern", Richter \& Richter 1926) seems not to follow any generalised evolutionary trend. Small advanced eyes that characterise most Frasnian phacopids in outer-shelf limestones are already developed in Early Devonian Reedops, which however have a much higher visual surface with significantly more lenses that are perfectly arranged in vertical rows. Similarly, the early Middle Devonian Chotecops exhibits advanced eye lobes leaving a conspicuous postocular space on the genal field. Whereas these forms occur in both biodetrital and muddy micritic biotopes, the descendant Chotecops koeneni group in the middle Givetian was exclusively adapted to off-shore cephalopod- and stylioline-bearing calcilutites. Following the Taghanic onlap this biotope became dominant in outer shelf domains of southern Europe and North Africa as well as on submarine rises in the Rhenish Slate Mountains and Thuringia. In these domains evolutionary trends towards eye reduction occur most commonly not only in the Phacopidae but also in the Proetida (e.g. Feist 1995). Most Frasnian phacopid genera are characterised by advanced eye lobes with low kidneyshaped visual surfaces with irregularly packed lenses arranged in vaguely discernible vertical rows. Initiated by Occitanella in the late early Frasnian this configuration remains relatively stable in numerous mid-Frasnian species of Chlupacops and Acutiphacops with only minor variation in the size of the ocular complex and the post- ocular distance from the posterior border of the cephalon. Successive populations of Acuticryphops acuticeps show a continuous reduction in mean lens numbers (Feist 1995, Crônier et al. 2004), whilst the original reniform visual surface, still developed in early morphs, assumes an elliptical outline of lens arrangement when the number of lenses decreases below eleven. At this stage of the cryptophthalmus pattern the remnant palpebral lobe has become minute and subtriangular, whereas its distal edge tends to straighten in upper view and to curve upwards in anterolateral view. Morphs in which a single lens remains are frequent in topmost Frasnian levels but the presence of blind morphs has not been established prior to the extinction event at the Upper Kellwasser horizon. As yet the only blind taxon from the Frasnian is Trimerocephaloides from FZ 13a of the Canning Basin (NW Australia) (Feist et al. 2009). Though devoid of any lenses, remnants of (functional?) ocular devices are still perceptible in the form of minute protuberances crossed by the facial suture in the anteriormost adaxial corner of the cheek. Such configuration is reminiscent of some species of early Famennian Pulvinocephalus, Trifoliops and Trimerocephalus though direct phyletic links between these taxa to latest Frasnian ones have not been established with certainty (Feist 2019).

\section{Aspects of phyletic relations and morphological traits}

The origin of the Late Devonian Phacopidae remains obscure due to the poor knowledge of representatives in the late Givetian. Regardless of the low eye lobes in Cronierella that might result from paedomorphic processes, many features of the cephalon such as the outline and vault of the glabella and the configuration of the intercalating ring are very close to late representatives of Eldredgeops. However possible phyletic links between these genera are contradicted by the fact that the pygidia are quite dissimilar and the question of phyletic relationships remains open until new discoveries of related taxa are made in late Givetian strata. Search for similarities based on traits of the cephalon alone are often biased by homeomorphy whereas morphological features of the pygidium in Late Devonian phacopids are obviously more stable and characteristic for defining genera. Changes in their morphology in the Frasnian concern essentially the axis that shortened to remain considerably distant from the posterior edge. This is perceptible in younger species of Cronierella in comparison to the initial species from the latest Givetian. It is more conspicuous in Occitanella and Girardina. The prolongation of the posterior end of the axis by a marked post-axial ridge as in Cronierella and Occitanella is outstanding in the Phacopidae, and as such 
may constitute an innovation. By contrast the pygidia of Chlupacops are devoid of postaxial ridges, but the axial furrows remain unclosed beside the rounded posterior tip of the axis. These are closed though shallow around the end of axes in both Acutiphacops and Acuticryphops, and remain unchanged in depth in Girardina.

Some early Famennian taxa such as Nephranops were considered by Chlupáč (1977) to be related to Chotecops, that was thought to persist into the Late Devonian with its putatively last representatives "Phacops" nalivkini Maximova, 1955 and "Phacops" pronini Maximova, 1955, both taxa being later tentatively reassigned respectively to Houseops Feist et al., 2009 and to Chlupacops (herein). The presumably last representatives of Chotecops constitute the mid-Givetian koeneni group, comprising Ch. koeneni (Holzapfel, 1895), Phacops s.l. (Ch.?) sp. n. aff. koeneni Basse \& Lemke, 1996 and Ch. spectabilis (Meischner, 1965), the latter probably being a synonym of koeneni. However, these taxa exhibit markedly smaller and more advanced eyes than the typical Eifelian species and allies. By these features the koeneni group is closest to representatives of Chlupacops and as such was questionably included in the latter by Feist et al. (2016). However there is a considerable time interval of some $3 \mathrm{Ma}$ between the late mid-Givetian Taghanic extinction of the koeneni group and the first Chlupacops in the mid-Frasnian (FZ 5), devoid of any morphologically intermediate taxa that would testify to possible direct evolutionary links between Chotecops and Chlupacops. Before more and better preserved material of the former would allow exhaustive evaluation of specific characters to be made, Chlupáč (1977) is followed in assigning the koeneni group to Chotecops, and considering this group the root stock of the Frasnian representatives of Chlupacops. As such and according to the scheme of phylogenetic development proposed by Chlupáč (1977, fig. 26) the Chotecops - Chlupacops line gave rise to the early Famennian Nephranops, and in particular to N. (Maternia) Feist, 2019, by extreme reduction until obsolescence of eye lenses on the visual surface. In addition, it gave rise also to other Famennian phacopids such as Houseops that shares with Chlupacops the anteriorly wide glabellar lobe, the advanced eye and the short pygidial axis.
Members of the phyletic lineage leading from Acuticryphops to Trimerocephalus suggested by many authors (i.e. Chlupáč 1977 and Feist 1995) are characterised by backwardly directed pre-vincular doublure, frontal overhang of the anteriorly pointed glabella in the cephalon, and a transverse pygidium with low and short axis. This configuration is partially developed in Acutiphacops which is considered the direct ancestor of Acuticryphops. However, the former is distinct through features that are typical for Phacops s.l., such as the narrow cylindrical border and deep border furrow, as well as the long postvincular doublure. Whether the suggested direct ancestor-descendant relation existed between Phacops and the Acuticryphops-Trimerocephalus line (Chlupáč 1977, fig. 26), with Acutiphacops as an intermediate, cannot be excluded but further knowledge of potentially intermediate taxa from the Givetian and early Frasnian is needed. Likewise, the question of ancestry of Occitanella and Girardina remains problematic and currently unsolved.

\section{Systematic paleontology}

Terminology follows Whittington \& Kelly (1997) and McKellar \& Chatterton (2009). Measurements of pygidial length do not include the articulating half ring.

Depository: UM-IP - University of Montpellier; Invertebrate Palaeontology (UM-IP 858-961).

Order Phacopida Salter, 1864

Family Phacopidae Hawle \& Corda, 1847

Subfamily Phacopinae Hawle \& Corda, 1847

\section{Genus Cronierella gen. nov.}

Type species. - Cronierella gallica sp. nov.

Etymology. - After Catherine Crônier (Lille) in recognition of her substantial work on Late Devonian phacopids.

Diagnosis. - Glabella moderately vaulted, not overhanging in front; palpebral furrow shallow; low eyes remaining in short distance from posterior border furrow, visual

Figure 4. All specimens from Montagne Noire, France. • A, B, D-I - Cronierella gallica sp. nov., La Serre.; A - fragmentary cephalon UM-IP 858, dorsal view; B - pygidium UM-IP 860, dorsal view; D - holotype cephalon UM-IP 862, anterior $\left(\mathrm{D}_{1}\right)$, dorsal $\left(\mathrm{D}_{2}\right)$, lateral $\left(\mathrm{D}_{3}\right)$ views; E - cephalon UM-IP 863, dorsal view; F - cephalon UM-IP 864, exfoliated, ventral view; G - hypostome UM-IP 866, ventral view; H - pygidium UM-IP 867, dorsal $\left(\mathrm{H}_{1}\right)$, lateral $\left(\mathrm{H}_{2}\right)$ views; I - fragmentary cephalon UM-IP 865, oblique lateral view. $\bullet \mathrm{C}$ - Cronierella? sp. nov. A, eastern slope of Mont Peyroux; cephalon UM-IP 861, dorsal $\left(\mathrm{C}_{1}\right)$, anterior $\left(\mathrm{C}_{2}\right)$, lateral $\left(\mathrm{C}_{3}\right)$ views. $-\mathrm{J}-\mathrm{L}-$ Cronierella postera sp. nov., La Serre; J - holotype cephalon UM-IP 872, dorsal $\left(\mathrm{J}_{1}\right)$, lateral $\left(\mathrm{J}_{2}\right)$, anterior $\left(\mathrm{J}_{3}\right)$ views; $\mathrm{K}$ - cephalon UM-IP 874, anteriorly fragmented, dorsal $\left(\mathrm{K}_{1}\right)$, lateral $\left(\mathrm{K}_{2}\right)$ views; $\mathrm{L}$ - pygidium UM-IP 875 , dorsal $\left(\mathrm{L}_{1}\right)$, lateral $\left(\mathrm{L}_{2}\right)$ views. $-\mathrm{M}, \mathrm{N}$ - Cronierella expansa sp. nov., La Serre; $\mathrm{M}$ - holotype cephalon UM-IP 876, dorsal $\left(\mathrm{M}_{1}\right)$, anterior $\left(\mathrm{M}_{2}\right)$ views; $\mathrm{N}$ - pygidium UM-IP 877 , lateral $\left(\mathrm{N}_{1}\right)$, dorsal $\left(\mathrm{N}_{2}\right)$ views. Scale $=1 \mathrm{~mm}$. 


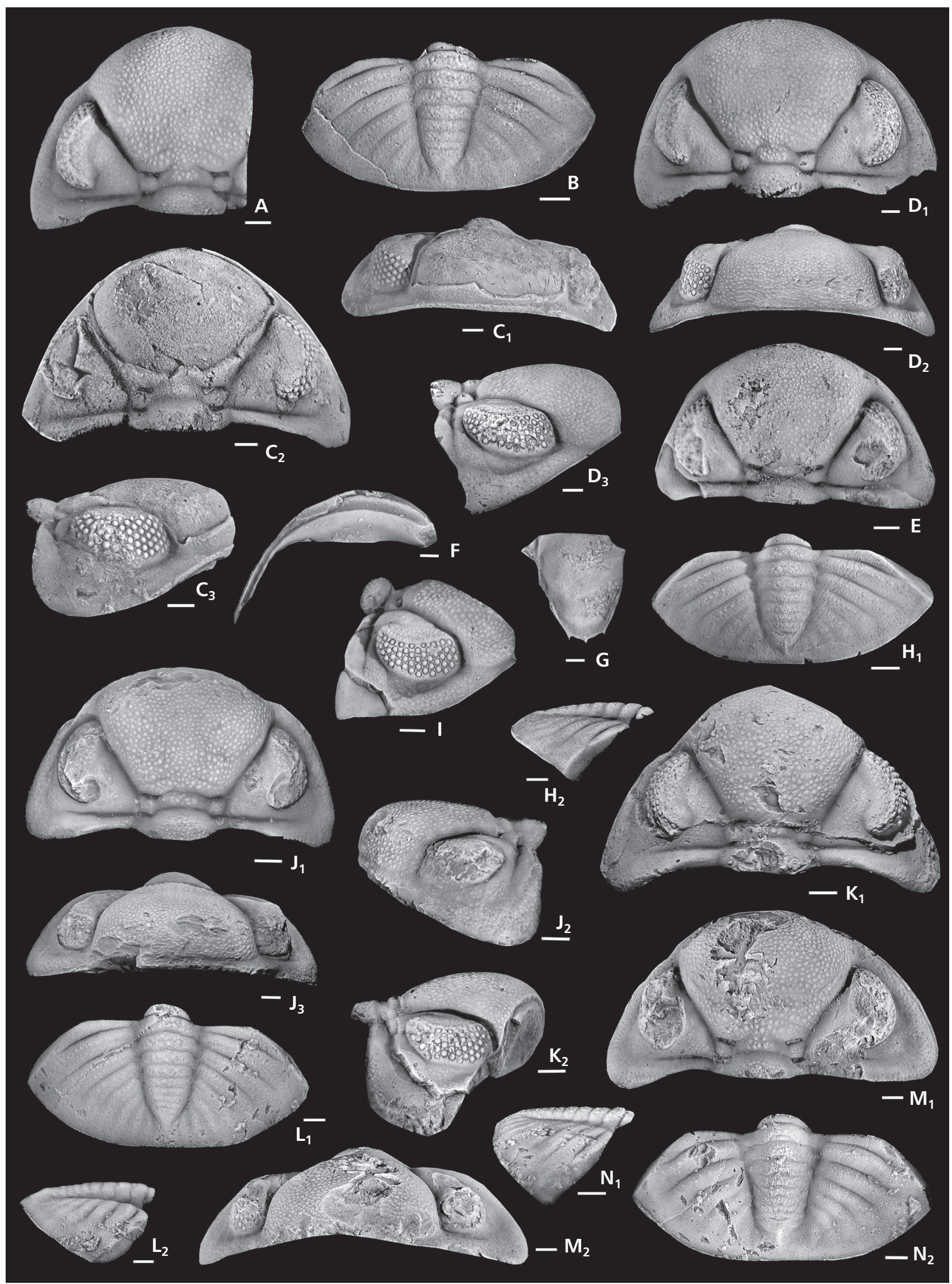


surface considerably reduced in height at the posterior end, with 16 rows of lenses containing a maximum of four (five?) lenses; pygidium transverse subpentagonal; axis narrow, low, with eight rings, with distinct postaxial ridge not reaching posterior edge; pleural field moderately vaulted with six to seven flat ribs defined by deep pleural furrows not reaching lateral margin. Sculpture of flat tubercles becoming elongated on frontal face of glabella, exoskeleton pitted.

Remarks. - The new genus regroups phacopine taxa with moderately inflated cephala with long, low eyes, and transverse pygidia with narrow, low axis not reaching the posterior edge. The outline and vault of the glabella and palpebral area bear resemblances with Eldredgeops and, in particular, with E. rana milleri from the Givetian Silica Formation, Michigan. Characters in common are the modest transverse vault of the glabella without anterior overhang, and the distinctly tri-lobed intercalating ring. Cronierella gen. nov. shares with the rana group in particular: absence of subocular ridge and subocular pad, wide palpebral area and lobe, shallow palpebral furrow, moderately inflated glabella with vertical front wall, and rectangular lateral nodes on the intercalating ring. Consistent differences concern the much lower eye lobe remaining below the level of the glabella and the outline of the visual field which is "pointed" behind. Whereas the number of vertical rows of lenses (16) in Cronierella occurs in members of Eldredgeops (15-18) and notably in E. rana milleri, the number of lenses per row is much higher in the latter. A specimen from the Tully Formation assigned to E. rana norwoodensis (Eldredge 1972, fig. 15d) has a similar number of lenses including one row with 5 lenses. I agree with A. Van Viersen (written communication) that this specimen is different from the type species of E. rana norwoodensis which is characterised by a significantly higher number of lenses in a row (4-6) (Eldredge 1972, fig. 15b). The pygidia of the new genus differ from Eldredgeops in their general shape, and the low, narrow axis with postaxial ridge that does not reach the posterior edge.

Occurrence. - Montagne Noire, France, Holy Cross Mts. Poland; latest Givetian (Upper disparilis?) norrisi Zone through lower Frasnian Zone 6.

Species included. - Cronierella gallica sp. nov., latest Givetian norrisi Zone; C. postera sp. nov., Frasnian Zone 6; C. expansa sp. nov., Frasnian Zone 6; all from La Serre, Montagne Noire. Cronierella zofiae (Chlupáč, 1993), latest Givetian, basal Szydlówek Formation, Holy Cross Mountains, Poland. Questionably assigned: Cronierella? sp. nov. A, Col des Tribes, Montagne Noire, late Givetian, Upper disparilis Zone.

\section{Cronierella gallica sp. nov.}

Figure 4D-I

Holotype. - Cephalon UM-IP 862, La Serre, Montagne Noire, norrisi Zone (Fig. 4D).

Type horizon and locality. - Microsparitic grey-brown trilobite coquina ("Phacops-bed"), Serre Formation, lower member (Feist 1985); La Serre hill, trench A'17, norrisi Zone, latest Givetian (Feist 1983, Feist \& Klapper 1985).

Other material. - Paratypes: cephala UM-IP 858, 863-865; hypostome UM-IP 866; pygidia UM-IP 860, 867; additional material: nine cephala (UM-IP 868), a hypostome (UM-IP 869), a thoracic segment (UM-IP 870), seven pygidia (UM-IP 871), all from type horizon and locality.

Etymology. - Gallicus [Lat.] $=$ from Gaul.

Diagnosis. - Glabella with high frontal wall; median lobe of distinctly tripartite intercalating ring ellipsoid, prominent; S1 curved forwards adaxially and interrupted medially; pygidium short, posterior outline wide parabolic, projection of maximum width opposite fourth axial ring. Axis long, slender, narrow anteriorly, pointed posteriorly; pleural field with seven low-vaulted ribs.

Description. - Cephalon distinctly longer than half width (58\% of width), moderately vaulted transversely, gently curved anteriorly. Degree of glabella divergence is moderate $\left(60^{\circ}-65^{\circ}\right)$. Anterior glabellar width more than twice width of intercalating ring, moderately vaulted, stronger in front where the height of glabella reaches $58 \%$ of length of its anterior lobe. Front wall of anterior glabella is high, slightly inflated, and does not overhang anterior border. Anterior border is framed by a thin, incomplete rim. Glabellar furrows S2 and S3 very thin, conspicuous but unimpressed in exoskeleton. Intercalating ring is markedly tripartite. Median lobe ovoid, inflated, carrying numerous tubercles, merging anteromedially with base of anterior glabellar lobe, distally separated from lateral lobes by broad, smooth depressions. Lateral lobes of intercalating ring largely subquadrangular with distinct adaxial edge, swollen, ornamented with small tubercles. S1 furrow directed forward adaxially, medially effaced. Occipital furrow gently rounded. Occipital ring twice as long as median lobe of intercalating ring, narrow (30\% of cephalic width), without lateral lobes. Vincular furrow gently curved, deep, distinct, abaxially narrowing to become a deep narrow grove with almost inconspicuous notches. Postvincular doublure is depressed posteriorly, with slightly downturned edge at hypostomal suture. Palpebral area wide, poorly inflated. Palpebral furrow faint, weak in smaller specimens. Palpebral lobe is wide, slightly swollen, about 
level with adaxial region of palpebral area. Eye is low, remaining below surface of anterior glabella, reaches anterolateral border furrow. Postocular genal field is half length (exsag.) of adjacent posterior border. Visual surface has 16 vertical rows of lenses with a maximum number of four lenses. Sclera in eyes thin throughout without sculpture. Base of visual surface lacks tubercles. Subocular groove has no pad. Subocular area of gena is narrow, slightly swollen, more so anterior to suture than posteriorly. Posterior branch of facial suture distinct. Posterior border furrow deep adaxially, fading away distally, very weak when meeting lateral border furrow in obtuse angle. Lateral border slightly inflated in transverse section, framed with narrow border rim. Sculpture: flat, dense tubercles, becoming elongated across anterior face of glabella and on anterolateral border; backwardly facing scaly tubercles on occipital ring, posterior border smooth. Surface of palpebral area and occipital ring markedly pitted, less obvious elsewhere. Postvincular doublure with wavy, short terrace ridges. Hypostome long semiellipsoid with straight hypostomal suture and narrow posterolateral border bearing three short spines at the posterior margin. Middle body is moderately vaulted; middle furrow very shallow, transverse; posterior lobe of middle body indistinct. Sculpture consists of thin tiny terrace ridges on anterior middle body and adaxial anterior wings. Thoracic segments without lateral axial lobes. Sculpture of axis with backwardly-facing, drop-like tubercles. Pygidium transverse, short (length is $43 \%$ of width), with wide parabolic posterior outline. Projection of maximum width crosses the middle of fourth axial ring. Axis low, narrow (width $=26 \%$ of pygidial width), long (length $=85 \%$ of total pygidial length), defined by straight, distinct, weakly converging axial furrows, with nine straight axial rings besides triangular terminal piece. Inter-ring furrows straight, distinct, reaching axial furrows, the anterior two with indistinct pseudoarticulating half-rings. Terminal piece flat, merging with broad postaxial ridge that narrows backwards, almost extending to posterior edge of pygidium. Pleural region moderately vaulted. Distance between axial furrow and fulcrum is $60 \%$ of distance between fulcrum and distal end of facet. There are seven moderately vaulted pleural ribs separated by deep thin pleural furrows. Interpleural furrows weak to indistinct. Anterior bands of ribs carrying a row of tubercles are slightly higher and longer than posterior ones. Ribs and pleural furrows almost reaching lateral edge of pygidium. Exoskeleton of pygidium pitted, with flat tubercles throughout that are densely crowded on anterior axial rings, and aligned on posterior ones and on pleural ribs. Posterolateral edge framed with thin rim.

Remarks. - This taxon was first presented in the unpublished thesis by Feist (1977) under the designation
Phacops (Chotecops?) hermannicristatus sp. nov., after the hermanni-cristatus Zone to which it was thought to belong. This name constitutes a nomen nudum as the new species remained hitherto unpublished. Detailed conodont research subsequently undertaken by the second author (G.K.) revealed the assignment of the horizon to the Lowermost asymmetricus Zone (= norrisi Zone) (Feist $\&$ Klapper 1985). To avoid confusion the new taxon is renamed here.

\section{Cronierella postera sp. nov.}

Figure 4J-L

Holotype. - Cephalon UM-IP 872, La Serre, Frasnian Zone 6 (Fig. 4J).

Type horizon and locality. - Grey-brown calcilutite, Serre Formation, lower member (Feist 1985); La Serre hill, trench A bed 133, Frasnian Zone 6 (Feist \& Klapper 1985).

Etymology. - Posterus $[$ Lat.] $=$ later, referring to the later occurrence as the type species.

Other material. - Paratypes: cephala UM-IP 873-874, pygidium UM-IP 875, all from type locality and horizon.

Diagnosis. - Frontal wall of glabella moderately elevated; intercalating ring with transverse, low median lobe distinctly separated from back of anterior glabella by continuous S1; pygidium long with slightly truncated posterior outline, projection of maximum width opposite to fifth axial ring, facet long, axis remaining distinctly distant from posterior edge.

Remarks. - In comparison with the type species, the anterior glabella is a little lower (height reaching 53\% of length of its anterior lobe), the anterior border slightly inflated, anterolateral borders framed by a thin rim, glabellar furrows S2 and S3 conspicuously impressed in exoskeleton, S1 continuous, curving forward medially. The intercalating ring is subdivided by shallow depressions, median lobe slightly curved, of even length medially to distally, conspicuously inflated (sag., exsag.). Postvincular doublure is horizontal. Eye lobe does not reach anterolateral border furrow. Postocular genal field is more than half length (exsag.) of adjacent posterior border. Sculpture: circular, low, dense tubercles, becoming elongated across ventral third of anterior face of glabella; tubercle row on posterior border; postvincular doublure with thin, discontinuous terrace ridges. Pygidium long (length is $47 \%$ of width) of subhexagonal outline, slightly truncated posteriorly. Projection of maximum width crosses back of fifth axial ring. Axis comprising $82 \%$ of total pygidial length remains distinctly distant 
from posterior edge of pygidium. Distance between axial furrow and fulcrum is $56 \%$ of distance between fulcrum and distal end of facet. Ribs and pleural furrows remain distant from lateral edge of pygidium. Exoskeleton of pygidium with scarce small tubercles, slightly increasing in size on axial rings.

\section{Cronierella expansa sp. nov.} Figure 4M, N

Holotype. - Cephalon UM-IP 876, La Serre, Montagne Noire, Frasnian Zone 6 (Fig. 4M).

Type horizon and locality. - Grey-brown calcilutite, Serre Formation, lower member (Feist 1985); La Serre hill, trench A bed 129, Frasnian Zone 6 (Feist \& Klapper 1985).

Etymology. - Expansus [Lat.] = expansive, referring to the transversely enlarged cephalon.

Other material. - Paratype: pygidium UM-IP 877 from trench A'42, equivalent level to type horizon; additional material: pygidium UM-IP 878, from A'42.

Diagnosis. - Cephalon wide, slightly longer than half width, S1 interrupted medially, median lobe of intercalating ring merging with anterior glabellar lobe. Pygidium long hexagonal with maximum width opposite sixth axial ring; axial furrow outwardly bowed on anterior two segments; axis hypobolic in outline posteriorly; eight axial rings with obvious pseudo-articulating half rings on anterior few; pleural field with six vaulted pleural ribs.

Remarks. - The new species is distinct by the wide parabolic outline of its cephalon that is a little longer than half width $(54 \%$ of width) and the degree of glabella divergence $\left(66^{\circ}\right)$. It shares with Cronierella postera the height of the glabella and the slightly impressed S2 and S3 furrows. Distinct features of the intercalating ring comprise the straight uninflated median lobe that merges with the back of the anterior glabellar lobe and the trapezoidal, low lateral lobes. Librigenal subocular area is unswollen, posterior branch of suture indistinct. The pygidium, of similar length as that of postera, has a subhexagonal outline and is markedly truncated posteriorly. Projection of maximum width crosses back of fifth axial ring. The axis with broad hypobolic posterior outline, is as short as in postera (length $=82 \%$ of total pygidial length), remaining distinctly distant from posterior edge of pygidium. Particular features concern the axial furrows that are steadily outwardly curved adjacent to rings in anterior half of axis, converging uniformly thereafter. Three anterior axial rings exhibit distinct pseudo-articulating half rings. Axial furrow are interrupted medially behind terminal piece by thin, prominent postaxial ridge that fades away half way to posterior edge of pygidium. There are six vaulted pleural ribs separated by distinctly deep pleural furrows. Ribs and pleural furrows do not extend to lateral edge of pygidium. Exoskeleton of pygidium is smooth except for scarce tubercles on anterior pleural ribs and median axial rings.

\section{Cronierella? sp. nov. A}

Figure 4C

Remarks. - A single cephalon (UM-IP 861) in light grey stylioline biomicrites of Upper disparilis Zone age was found on the eastern slope of Mont Peyroux hill near Col des Tribes (locality 7, CT-S section, bed 50 with Polygnathus cristatus and P. dengleri). The outline of the cephalon and glabella, and in particular the disposition of the intercalating ring and the occipital lobe, resemble traits of Eldredgeops. However, the palpebral area is much narrower (tr.), the palpebral furrow well discernible, the eye shorter, remaining farther from the posterior border furrow, and is lower with fewer lens rows (17) and lenses (a maximum of five in a row). In these features the taxon is very close to Cronierella, with the exception of the higher number of lenses that protrude from the scleral surface. We tentatively assign this taxon to Cronierella; its definite attribution is hindered by the currently missing pygidium. Awaiting additional material, we leave this taxon unnamed but consider it to be a new species.

\section{Genus Acutiphacops gen. nov.}

Type species. - Acutiphacops medius sp. nov.

Etymology. - After the acute anterior outline of cephalon.

Diagnosis. - Cephalon of narrow parabolic outline; almost flat-topped, pentagonal pre-occipital glabella with long anterior portion overhanging anterior border; short, cylindrical, protruding previncular doublure, edges of vincular furrow of similar elevation, long postvincular doublure; anteriorly situated high eyes with 12 rows of maximum four lenses; pygidium transverse, short, with moderately high axis remaining distant from posterior margin, 5-6 axial rings besides end-piece.

Remarks. - The new genus regroups taxa combining features that characterise Acuticryphops (anteriorly pointed, overhanging glabella, transverse pygidium with short axis) and, on the other hand, Phacops (facial suture running in deep border furrow, discrete cylindrical border, long postvincular doublure, visual surface considerably higher in front than to the rear). Notably, the pygidium is 
very close to that of Acuticryphops. The new genus might represent the direct ancestor of Acuticryphops.

Occurrence. - Frasnian Zones 8-10, Montagne Noire (France), Tafilalt (Morocco).

Species included. - Acutiphacops medius sp. nov., Frasnian Zone 8, La Serre, Montagne Noire, France; $A$. erfoudensis (Richter \& Richter, 1943), Late Devonian undetermined, A. tchrafinensis sp. nov., both Tafilalt, Morocco.

\section{Acutiphacops medius sp. nov.}

Figure 5D-G

Holotype. - Cephalon UM-IP 883, La Serre, Montagne Noire, Frasnian Zone 8 (Fig. 5D).

Type horizon and locality. - Coarse light-grey crinoidal calcirudite, section La Serre A' bed 71 (Klapper 1989, pl. 2, fig. 10; Feist 2002, fig. 30b).

Etymology. - Medius [Lat.] $=$ in between (Phacops and Acuticryphops).

Other material. - Paratypes: cephala UM-IP 884-885, pygidia UM-IP 886-887, all from type horizon and locality; additional material: four cephala UM-IP 888-891, two pygidia UM-IP 892-893 from type horizon and locality.

Diagnosis. - Cephalon with strongly diverging axial furrows; glabella with marked anterior overhang; anterior border furrow deep, anterior border narrow cylindrical, protruding, post-vincular doublure long; eye lobe three times longer than postocular genal field, encroaching onto anterolateral border for $75 \%$ of its length; pygidium transverse, truncated behind, five axial rings with sigmoidal inter-ring furrows, posterolateral margins without border.

Description. - Cephalon long (length $62 \%$ of width), of narrow parabolic outline. Anterior glabellar lobe is pentagonal, with obtusely pointed anterior contour, of very low, weakly vaulted lateral and transverse profiles, anteriorly a little higher than half length, with strong anterior overhang. Length is $74 \%$ of width. Portion anterior to maximum width is $48 \%$ of posterior portion. Axial furrows diverge at $84^{\circ}$; they are straight behind before their inward deviation by slight impingement of adaxial eye lobe on anterior glabella shortly behind inwardly-curved, bluntly-rounded glabellar corners. S1 slightly convex forward, shallow medially; S2 are ovoid depressions; S3 very week. Intercalating ring is narrow (tr.)
(31\% of cephalic and $49 \%$ of maximum glabellar width), tripartite, with band-like median lobe and well defined circular, slightly inflated and backwardly extending lateral lobes. Occipital ring twice as long as intercalating ring (sag.), extending forwards medially, without lateral lobes. Eye lobe is prominent, three times longer (exsag.) than distance between eye lobe and posterior border furrow, encroaching on to anterolateral border. Palpebral lobe wide (tr.), slightly inclined adaxially, with palpebral rim. Palpebral furrow deep, slightly convex outwards, visual surface kidney-shaped, moderately inclined abaxially, with 12 rows of lenses with a maximum of four in a row. Genal field gently vaulted. Facial suture meets subocular groove at the junction with lateral border furrow. Posterior and lateral border furrows rather deep, of even depth and mergeing with each other in obtuse angle. Anterolateral border furrow deviated by forward extension of eye lobe. Anterior border furrow deep. Anterior border is narrow cylindrical, rim-like, extending along edges of gently vaulted anterolateral borders. Vincular furrow deep, short (sag.), of circular curvature. Edges of vincular furrow are at same level. Postvincular doublure long (sag.), flat, densely covered with tiny short terrace ridges. Sculpture: entire surface of cephalon is densely covered with tubercles. Pygidium short (length $=43 \%$ of width) with angular anterolateral margins. Anterior edge between axial furrow and fulcrum is half as long as anterolateral edge. Posterior outline is straight or slightly embayed medially. Axis robust, high anteriorly, of moderate transverse vault behind, slightly curved in lateral profile with posterior end slightly elevated above postaxial field, wide (31\% of pygidial width), short (77\% of pygidial length), defined by deep, straight weakly tapering axial furrows that only partly surround the broadly rounded posterior end of axis, being interrupted medially by a short, weak postaxial ridge. There are five straight axial rings besides end piece. The two anterior rings exhibit small pseudo-articulating half-rings. First two inter-ring furrows reach axial furrows. Posterior inter-ring furrows slightly forwardly curved medially. Pleural field horizontal adaxially, rapidly downcurved abaxially, carrying five moderately elevated, almost straight ribs that are well defined by deep pleural furrows dying out well before reaching posterior margin, leaving a broad, uninflated border region. Surface of pygidium with spaced granules on axial rings and ribs.

\section{Acutiphacops erfoudensis (Richter \& Richter, 1943)}

1943 Phacops (Phacops) erfoudensis n. sp; Richter \& Richter, pp. 131-133, pl. 1, fig. 4.

1977 Phacops (Chotecops?) erfoudensis. - Chlupáč, p. 50.

Remarks. - Richter \& Richter described rather fragmentary phacopid material found by Termier (1936) in a loose rock 
sample with Late Devonian ammonoids in the region of Erfoud (SE Morocco). Despite the incompleteness of the trilobite remains and the uncertainty of both locality and age, they assigned the material to the new species Phacops erfoudensis, assuming a late Upper Devonian age for it as they considered its affinities to be with Phacops granulatus (Münster, 1840) and allies. Different characters, in particular the pentagonal outline and overhang of the anterior glabellar lobe along with the encroachment of the eye lobe onto the glabella adaxially are typical of the new genus, to which erfoudensis is assigned here. As it is most closely related to Acutiphacops tchrafinensis sp. nov. of mid-Frasnian age we assume a similar age for erfoudensis.

\section{Acutiphacops tchrafinensis sp. nov.}

Figure 5A-C

Holotype. - Cephalon UM-IP 879, Bou Tchrafine, Tafilalt, Morocco, Frasnian Zone 10 (Fig. 5A).

Type horizon and locality. - Grey marly calcilutite, section Bou Tchrafine W, bed N (Becker \& House 2000, fig. 1).

Etymology. - After locality Bou Tchrafine south of Erfoud, Morocco.

Other material. - Paratypes: cephalon UM-IP 880, pygidium UM-IP881; additional material: cephalon UM-IP 882.

Diagnosis. - Cephalon with moderate divergence of axial furrows and moderate glabellar overhang; eye lobe twice as long as postocular genal field, subocular groove merging with lateral border furrow anteriorly well in front of junction of facial suture with border furrow; pygidium gently rounded posteriorly, with six straight axial rings and a slightly inflated border laterally and posteriorly.

Remarks. - In comparison with the type species the new species has distinct features as follows. The cephalon is a little longer (length is $65 \%$ of width) and the anterior glabellar lobe, of which the length reaches $78 \%$ of its width, has only a slight anterior overhang. Axial furrows diverge at $67^{\circ}$ and are inwardly deviated by marked en- croachment of adaxial eye lobe on anterior glabella just behind angular corners of glabella. S1 transverse, slightly shallowing medially; S2 and S3 are discernible on internal mould. Intercalating ring is narrow (width $=34 \%$ of cephalic width), with narrow ridge-like median lobe and low, uninflated lateral lobes. Occipital ring short (sag.), as long as intercalating ring, scarcely extending forwards medially. Eye lobe is twice as long as distance between eye lobe and posterior border furrow, its anterior lower edge lying in the border furrow for a third of the length of the eye. Palpebral furrow deep, slightly convex outwards. Facial suture meets subocular groove at the posterior end of eye lobe, leaving a triangular strip of librigenal field between eye lobe and lateral border furrow. Sculpture consists of spaced, small drop-like tubercles on glabella and genal fields, lateral borders smooth. Anterior edge of pygidium between axial furrow and fulcrum is markedly shorter than length of anterolateral edge (64\%). Posterior outline gently curved. Axis of moderate height, with sagittal profile merging behind with vaulted postaxial field, wide (28\% of pygidial width), short (79\% of pygidial length). There are six straight axial rings besides end-piece (which may contain relicts of two supplement axial rings). The second ring exhibits small pseudo-articulating half-ring. Pleural field moderately vaulted with four ribs and a slightly inflated border region. Posterior edge of pygidium framed by marked rim. Surface of pygidium is granulose with a few tiny tubercles on anterior axial rings and ribs.

The new species differs from its nearest relative A. erfoudensis by a longer eye-lobe with a higher number of lens rows, weaker divergence of axial furrows, lesser density of tuberculation and an un-crested posterior axis of pygidium. A closely related fragmentary cephalon was recovered from Frasnian Zone 10 of the Bou Tchrafine section by Helling \& Becker (2012). A digital photograph of it, provided by S. Helling, reveals a very fine and dense granular sculpture unlike that of tchrafinensis; it might belong to a different probably new species.

\section{Genus Acuticryphops Crônier \& Feist, 2000}

Type species. - Trimerocephalus acuticeps Kayser, 1889; Adorf, Rhenish Slate Mountains, Late Frasnian.

Figure 5. Specimens from Montagne Noire, France, except in A-C, M, N. • A-C - Acutiphacops tchrafinensis sp. nov., Bou Tchrafine, Tafilalt, Morocco; A - holotype cephalon UM-IP 879, dorsal $\left(A_{1}\right)$, ventral $\left(A_{2}\right)$, anterior $\left(A_{3}\right)$ views; $B$ - fragment of cephalon UM-IP 880, dorsal $\left(B_{1}\right)$, lateral $\left(\mathrm{B}_{2}\right)$ views; $\mathrm{C}$ - pygidium UM-IP 881, lateral $\left(\mathrm{C}_{1}\right)$, dorsal $\left(\mathrm{C}_{2}\right)$ views. $\cdot \mathrm{D}-\mathrm{G}-$ Acutiphacops medius sp. nov., La Serre; $\mathrm{D}-$ holotype cephalon UM-IP 883, dorsal $\left(\mathrm{D}_{1}\right)$, lateral $\left(\mathrm{D}_{2}\right)$, anterior $\left(\mathrm{D}_{3}\right)$ views; E -cephalon UM-IP 884, partly exfoliated, ventral $\left(\mathrm{E}_{1}\right)$, dorsal $\left(\mathrm{E}_{2}\right)$ views; F - cephalon UM-IP 885, dorsal view; $\mathrm{G}$ - pygidium UM-IP 886, posterior $\left(\mathrm{G}_{1}\right)$, lateral $\left(\mathrm{G}_{2}\right)$, dorsal $\left(\mathrm{G}_{3}\right)$ views. $-\mathrm{H}-\mathrm{J}$ - Acuticryphops prorotundus sp. nov.; $\mathrm{H}$ - holotype cephalon UM-IP 894 from Combe Rolland, ventral $\left(\mathrm{H}_{1}\right)$, dorsal $\left(\mathrm{H}_{2}\right)$, anterior $\left(\mathrm{H}_{3}\right)$ views; I - cephalon UM-IP 896 from La Serre, dorsal $\left(\mathrm{I}_{1}\right)$, lateral $\left(\mathrm{I}_{2}\right)$ views; $\mathrm{J}$ - pygidium UM-IP 895 from Combe Rolland, anterior $\left(\mathrm{J}_{1}\right)$, lateral $\left(\mathrm{J}_{2}\right)$, dorsal $\left(\mathrm{J}_{3}\right)$ views. $\bullet \mathrm{K}-\mathrm{N}-$ Acuticryphops acuticeps, K-L from Coumiac, M-N from Kahlleite Quarry, Thuringia, Germany; $\mathrm{K}$ - cephalon UM-IP 900, early form, ventral $\left(\mathrm{K}_{1}\right)$, dorsal $\left(\mathrm{K}_{2}\right)$, lateral $\left(\mathrm{K}_{3}\right)$ views; $\mathrm{L}$ - pygidium UM-IP 901, early form, lateral $\left(\mathrm{L}_{1}\right)$, dorsal $\left(\mathrm{L}_{2}\right)$ views; $\mathrm{M}$ - cephalon UM-IP 902, dorsal $\left(\mathrm{M}_{1}\right)$, lateral $\left(\mathrm{N}_{2}\right)$ views; $\mathrm{N}$ - pygidium UM-IP 903, dorsal view. Scale $=1 \mathrm{~mm}$. 


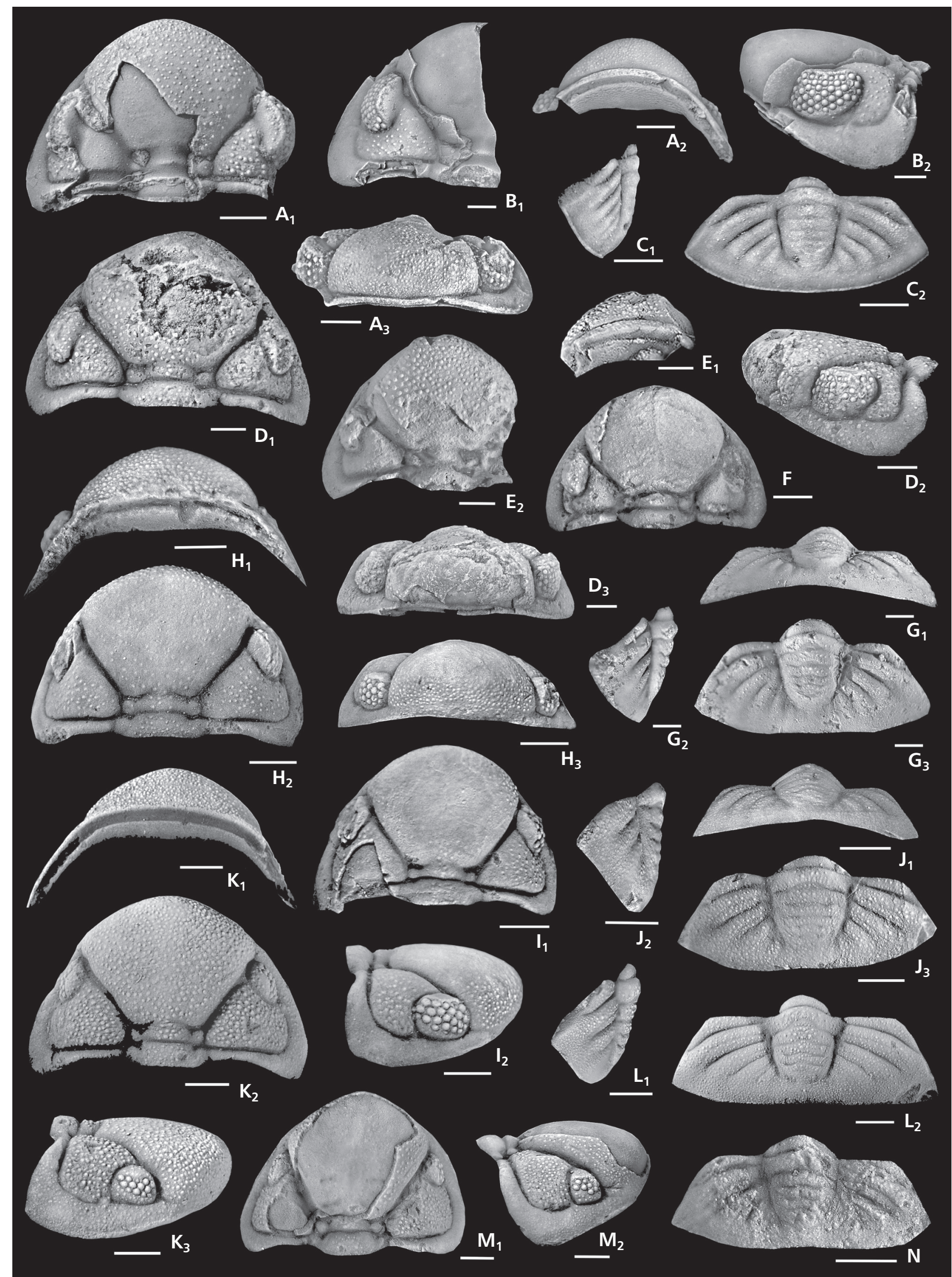


Diagnosis (emended). - Cephalon with inverted lensshaped previncular doublure merging with overhanging anterior glabella, continuously deep vincular furrow, narrow postvincular doublure; anterior outline of glabella rounded to obtusely pointed; eye lobe small, ovoid, as high in front as to the rear in anterolateral view, encroaching onto anterolateral border, palpebral furrows straight and diverging forward to slightly concave abaxially, merging with subocular groove in continuous curvature and depth, visual surface variably kidney shaped to oval with one to 23 lenses. Pygidium transverse, short, with low axis carrying five rings besides short end piece that does not reach posterior margin.

Species included. - Acuticryphops acuticeps (Kayser, 1889), Frasnian Zones 12-13, Rhenish and Thuringian Slate Mountains, Harz, England, Moravia, Montagne Noire, Hercynian Meseta of Morocco, NW Algerian Sahara, Canning Basin of Western Australia; A. klapperi Feist et al., 2009, Frasnian Zone 13, Canning Basin, Western Australia; A. prorotundus sp. nov., Frasnian Zone 13, Montagne Noire.

Occurrence. - Western and Central Europe, North Africa, Western Australia.

Acuticryphops prorotundus sp. nov. Figure 5H-J

1993 Nephranops sp. - Becker, p. 66.

Holotype. - Cephalon UM-IP 894, Combe Rolland, Montagne Noire, Frasnian Zone 13 (Fig. 5H).

Type horizon and locality. - Dark brown calcilutite, Combe Rolland road section at $2 \mathrm{~m}$ below top, SW of Vailhan village.

Other material. - Paratypes: pygidium UM-IP 895 from type horizon; cephalon UM-IP 896 from La Serre section C, bed 13, Frasnian Zone 13 (Klapper in Feist 1990, fig. 28); additional material: three cephala and two pygidia from type horizon and locality (UM-IP 897); 13 cephala, a thoracic segment and three pygidia from La Serre C, bed 13 (UM-IP 898); four cephala and three pygidia from Soureillé d'Izarne SW of Cabrières (UM-IP 899).

Etymology. - Prorotundus [Lat.] = rounded in front.

Diagnosis. - Cephalon of evenly rounded contour with bluntly curved glabellar corners, straight divergent palpebral furrows, long, flat palpebral lobes, ovoid eyes distant from posterior border furrow by three quarters of their length, lens-shaped palpebral lobes, kidney-shaped visual field with at least 18 lenses. Pygidium with wide axis of parabolic posterior contour, straight inter-ring furrows.

Description. - Cephalon markedly longer than wide (length/ width ratio $=0.64$ ), evenly rounded in outline, of moderate transverse vault. Anterior glabellar lobe has a rounded anterior contour, and is continuously high-vaulted transversely, less so in lateral profile except in front, where it is high (height in front of eye reaches $60 \%$ of length (sag.) of anterior glabellar lobe), strongly down-curved with marked anterior overhang. Axial furrows straight and diverging at $82^{\circ}$ between $\mathrm{S} 1$ and junction with palpebral furrow, slightly curving inwards in front to form bluntly rounded glabellar corners. S1 furrow is slightly convex forward, shallow medially; S2 rather weak, unimpressed. Intercalating ring is narrow (tr.) (29\% of cephalic and $46 \%$ of glabellar width), vaguely tripartite, with bandlike, uninflated median lobe and poorly differentiated, low, small lateral lobes not extending backward. Occipital furrow slightlycurved forwards medially in parallel with S1, gently set back behind lateral lobes of intercalating ring. Occipital ring short, less than twice length of intercalating ring (sag.), scarcely extending forwards medially, notched anterolaterally and diminishing in length distally (exsag.), with weakly differentiated lateral lobes. Genal field evenly vaulted. Eye is ovoid in anterolateral view, surrounded by deep palpebral and subocular furrows, encroaching far onto anterolateral border. Distance between posterior border and eye is $79 \%$ of eye length (exsag.). Palpebral furrows straight, divergent. Palpebral lobes lens-shaped, long (exsag.), flat, bare, rearwards inclined, without palpebral rim. Visual surface is kidney shaped with palpebral suture dorsally concave in lateral view, as high in front as to the rear. There are between 18 and 23 lenses irregularly and densely arranged, markedly protruding above reduced sclera. Posterior facial suture runs on tiny triangular bridge interrupting lateral border furrow. Posterior and lateral border furrows merging in a uniformaly deep, parabolic curve. Borders slightly vaulted, widest opposite obtusely rounded genal angle. Anterolateral border narrowing adaxially to merge with inverted, crescent shaped previncular doublure. Vincular furrow deep throughout, scarcely curved medially. Postvincular doublure twice as long (sag.) as vincular furrow. Sculpture: tiny tubercles that are dense on anterior face of glabella, elsewhere widely spaced, tending to vanish on medial part of anterior glabella; palpebral lobes, lateral lobes of intercalating ring, posterior and lateral borders and postvincular doublure smooth. Pygidium transversely subrectangular (length/width ratio $=0.38$ ) with curved, medially slightly transverse posterior outline. Axis is low, very wide (one-third of pygidial width), with five flat axial rings besides end piece, the first ring more 
strongly vaulted, the second with pseudo-articulating half-ring. Inter-ring furrows straight, shallowing medially, do not reach axial furrows except first one. Axial furrows weakly tapering anteriorly, more strongly behind third ring, vanishing without postaxial closure distant from posterior edge of pygidium. End piece of axis extends rearwards, where it is slightly swollen, narrows, and almost reaches posterior edge. Pleural field slightly vaulted, with four poorly vaulted pleural ribs, defined by deeply marked pleural furrows. Interpleural furrows are discernible. Ribs and furrows remain far from posterolateral borders. Sculpture: medium-sized tubercles throughout.

Remarks. - The new species is close to early morphs of Acuticryphops acuticeps. The main differences in the former are the outline of the anterior glabellar lobe which is not pentagonal as a result of the inward curvature of the axial furrows anteriorly; the palpebral lobes are markedly wider; and the eye is much longer with a kidney-shaped (instead of oval) visual surface having more lenses. In addition, the pygidium has a much broader axis with straight inter-ring furrows. Specimens from locality $\mathrm{La}$ Serre C bed 13 were eronously assigned to Nephranops by Feist (in Becker 1993, p. 66).

\section{Acuticryphops acuticeps (Kayser, 1889)}

Figure $5 \mathrm{~K}-\mathrm{N}$

2009 Acuticryphops acuticeps. - Feist et al., pp. 24-27, fig. $5 \mathrm{a}-\mathrm{q}$ (earlier synonymies herein).

2016 Acuticryphops acuticeps. - McNamara \& Feist, p. 257, figs 2, 3 .

Material. - Cephalon UM-IP 900, pygidium UM-IP 901, early form, Coumiac Upper Quarry bed 21, Frasnian Zone 12; cephalon UM-IP 902, pygidium UM-IP 903, Kahlleite Quarry, Thuringia, Frasnian Zone 12.

Remarks. - Acuticryphops acuticeps is the most common and widely distributed phacopid species in Frasnian sections prior to its extinction at the base of the Upper Kellwasser horizon. Outstanding evidence of intraspecific variation in the number of eye lenses of the visual surface was analysed in successive populations of the Coumiac section by Feist (1991), Feist \& Schindler (1994) and Crônier et al. (2004). During the existence of the taxon trends related to eye reduction concern the outline and position of the eye lobe that reduces in size from behind to a small, subtriangular bulbous lobe. Reduction of eye lens numbers is concomitant with continuous transformation of the outline of the visual surface from an initial kidneyshaped pattern to an oval one where the palpebral lobe is triangular and the palpebral suture is dorsally convex in anterolateral view ("cryptophthalmus pattern" of Richter \& Richter 1926). Early morphs such as those presented here (Fig. 4L) have a kidney-shaped visual surface with 14 or more lenses. In addition to the variation in features of the eye lobe, populations of early morphs vary in the degree of curvature of the anterior glabellar outline, and in the length and degree of curvature of the postvincular doublure.

\section{Genus Occitanella gen. nov}

Type species. - Occitanella hexagonalis sp. nov.

Etymology. - After Occitania, Roman province in southern Gaul.

Diagnosis. - Cephalon with moderately vaulted glabella without anterior overhang, small forwardly placed eyes not reaching anterolateral border furrow, long and shallow vincular furrow with low inflated posterior edge, markedly convex postvincular doublure; hypostome with conspicuously continuous median furrow and inflated posterior lobe. Pygidium long, with short, narrow axis, long postaxial ridge and postaxial field.

Remarks. - We assign the Australian taxon Trimerocephaloides? linguiformis Feist et al., 2009 to the new genus Occitanella with question on account of the considerable length of the pygidium with rather short axis prolonged by an extended postaxial ridge, characters that are as such only known in Occitanella. However the new assignment must be reconsidered when cephalic characters of linguiformis become available.

Occurrence. - Early Frasnian zones 3 and 4 (Montagne Noire), Zone 11? (Canning Basin, NW Australia).

Species included. - Occitanella hexagonalis sp. nov., Frasnian Zone 3, Pic de Bissous, Montagne Noire; O. postinflexa sp. nov., Col du Puech de la Suque, Frasnian Zone 4, Montagne Noire. Assigned with question: O.? linguiformis (Feist et al., 2009), Frasnian Zone 11, Canning Basin, NW Australia; O.? sp. Frasnian Zone 4, Mont Peyroux, Montagne Noire.

\section{Occitanella hexagonalis sp. nov.}

Figure 6A-C

Holotype. - Pygidium UM-IP 904, Pic de Bissous, Montagne Noire, Frasnian Zone 3 (Fig. 6B).

Type horizon and locality. - Brick-red calcilutite, section VS-E, bed 49 (Feist 1983, fig. 13; Klapper 1985, fig. 1), southern steep face of Pic de Bissous. 
Etymology. - Hexagonalis [Lat.], after the outline of the pygidium.

Other material. - Paratypes: cephala UM-IP 905-906; additional material: four cephala UM-IP 908 and two pygidia UM-IP 909; all from type locality and horizon.

Diagnosis. - Cephalon with narrowly parabolic anterior outline, anterior axial furrows inwardly curved around glabella corners, marked palpebral rim; pygidium hexagonal with high axis, prominent first axial ring, curved pleural ribs, inconspicuously rounded lateral and posterior margins with slightly embayed posterior edge.

Description. - Cephalon long (length $=64 \%$ of width) with parabolic anterior outline. Anterior glabellar lobe bulbous, slightly pointed in front, long ( $76 \%$ of cephalic length), of high transverse vault, moderately vaulted in lateral profile, vertically sloping anteriorly without overhang. Anterior border thick, rounded in sagittal profile, protruding. Axial furrows anterior to intercalating ring are straight, diverging at $66^{\circ}$ until eye lobe, curving inwards around frontal glabellar lobe. S1 straight, shallowing medially, S2 and $\mathrm{S} 3$ indiscernible. Width (tr.) of intercalating ring is $56 \%$ of anterior glabellar width and one-third of cephalic width, is indistinctly tripartite: median lobe elongated, prominent, poorly separated from low lateral lobes. Occipital furrow deep, straight. Occipital ring is of moderate length (sag.), twice that of median intercalating ring, moderately vaulted (sag.), without lateral lobes. Eye short (distance between visual surface and posterior border furrow $=$ $70 \%$ of eye-length), reaching anterolateral border furrow. Visual surface kidney shaped, strongly sloping abaxially, distinctly vaulted dorsoventrally, with 11 vertical rows of lenses with a maximum of four per row (35 lenses in total). Palpebral lobes are crescent shaped, framed by thick palpebral rim. Palpebral furrows are distinct, continuous, diverging forward and almost straight. Posterior and lateral border furrows continuously deep and merging with each other in an obtuse angle. Vincular furrow is very wide (sag.) and shallow, with medially rounded, low posterior edge. Postvincular doublure is twice as long as vincular furrow (sag.), inflated medially, with slightly curved hypostomal suture. Sculpture consists of coarse granules throughout, finer on borders. Postvincular doublure is densely covered with thin discontinuous terrace ridges.

Pygidium is distinctly long (length/width ratio $=61 \%$ ), with pronounced hexagonal outline and long anterolateral contour. Anterior margin is distinctly shorter (tr.) than anterolateral margin $(64 \%)$. Posterior margin is narrow (tr.), slightly embayed medially. Projection of maximum pygidial width crosses sixth axial ring. Axis is narrow ( $29 \%$ of pygidial width), strongly convex across first ring, distinctly subdued thereafter, short (65\% of pygidial length). Axial furrows converge in a straight line except around end piece of axis where they converge more strongly and are interrupted by postaxial ridge. There are six-seven axial rings (besides end-piece), the first one higher and distinctly longer (sag.), the last ones poorly defined. Inter-ring furrows straight, wide (sag.) and shallow, not reaching axial furrows, except anterior two that are deeper and curve backwards distally. End piece is triangular, low, merging medially with distinct postaxial ridge that dies out mid-way to posterior edge of pygidium. Pleural field is wide, horizontal adaxially, strongly downcurved distally, with six ribs whose posterior bands are distinctly elevated, forming slightly backwardly curved crests that almost reach posterolateral margins. First pleural furrows markedly incised, remainder much shallower. Lateral and posterior margins with almost inconspicuously swollen border. Exoskeleton of pygidium is granulose.

\section{Occitanella postinflexa sp. nov.}

Figure 6D-K

Holotype. - Pygidium UM-IP 910, Col du Puech de la Suque, Montagne Noire, Frasnian Zone 4 (Fig. 6D).

Type horizon and locality. - Grey-brown calcilutite with Erbenicoryphe nazairensis Feist, 2003, section CPS-E, bed 58 (Feist \& Klapper 1985, fig. 5)

\section{Etymology. - Postinflexus [Lat.] = embayed behind.}

Other material. - Paratypes: cephala UM-IP 911-913, hypostome UM-IP 914, pygidia UM-IP 915-917; additional material: eight cephala UM-IP 918, four pygidia UM-IP 919.

Figure 6. All specimens from Montagne Noire, France. - A-C - Occitanella hexagonalis sp. nov., Pic de Bissous; A - cephalon UM-IP 905, dorsal $\left(A_{1}\right)$, lateral $\left(A_{2}\right)$, ventral $\left(A_{3}\right)$, anterior $\left(A_{4}\right)$ views; $B$ - holotype pygidium UM-IP 904, posterior $\left(B_{1}\right)$, lateral $\left(B_{2}\right)$, dorsal $\left(B_{3}\right)$, dorsal (latex cast of external mould, $\mathrm{B}_{4}$ ) views; C - fragmentary cephalon UM-IP 906, dorsal view. $・ \mathrm{D}-\mathrm{K}$ - Occitanella postinflexa sp. nov., Col du Puech de la Suque; D - holotype pygidium UM-IP 910, dorsal $\left(D_{1}\right)$, lateral $\left(D_{2}\right)$, posterior $\left(D_{3}\right)$ views; E - cephalon UM-IP 911, dorsal $\left(E_{1}\right)$, lateral $\left(E_{2}\right)$ views; F - hypostome UM-IP 914, ventral view; G - pygidium UM-IP 915, dorsal view; $\mathrm{H}$ - pygidium UM-IP 916, lateral $\left(\mathrm{H}_{1}\right)$, dorsal $\left(\mathrm{H}_{2}\right)$ views; I - exfoliated cephalon UM-IP 912, dorsal view; J - fragmentary cephalon UM-IP 913, latex cast of external mould, dorsal view; K - pygidium UM-IP 917, dorsal view. • L, M - Occitanella? sp., Mont Peyroux; $\mathrm{L}$ - cephalon UM-IP 921, ventral $\left(\mathrm{L}_{1}\right)$, lateral $\left(\mathrm{L}_{2}\right)$, dorsal $\left(\mathrm{L}_{3}\right)$, anterior $\left(\mathrm{L}_{4}\right)$ views; $\mathrm{M}$ - pygidium UM-IP 920, lateral $\left(\mathrm{M}_{1}\right)$, dorsal $\left(\mathrm{M}_{2}\right)$, posterior $\left(\mathrm{M}_{3}\right)$ views. Scale $=1 \mathrm{~mm}$. 


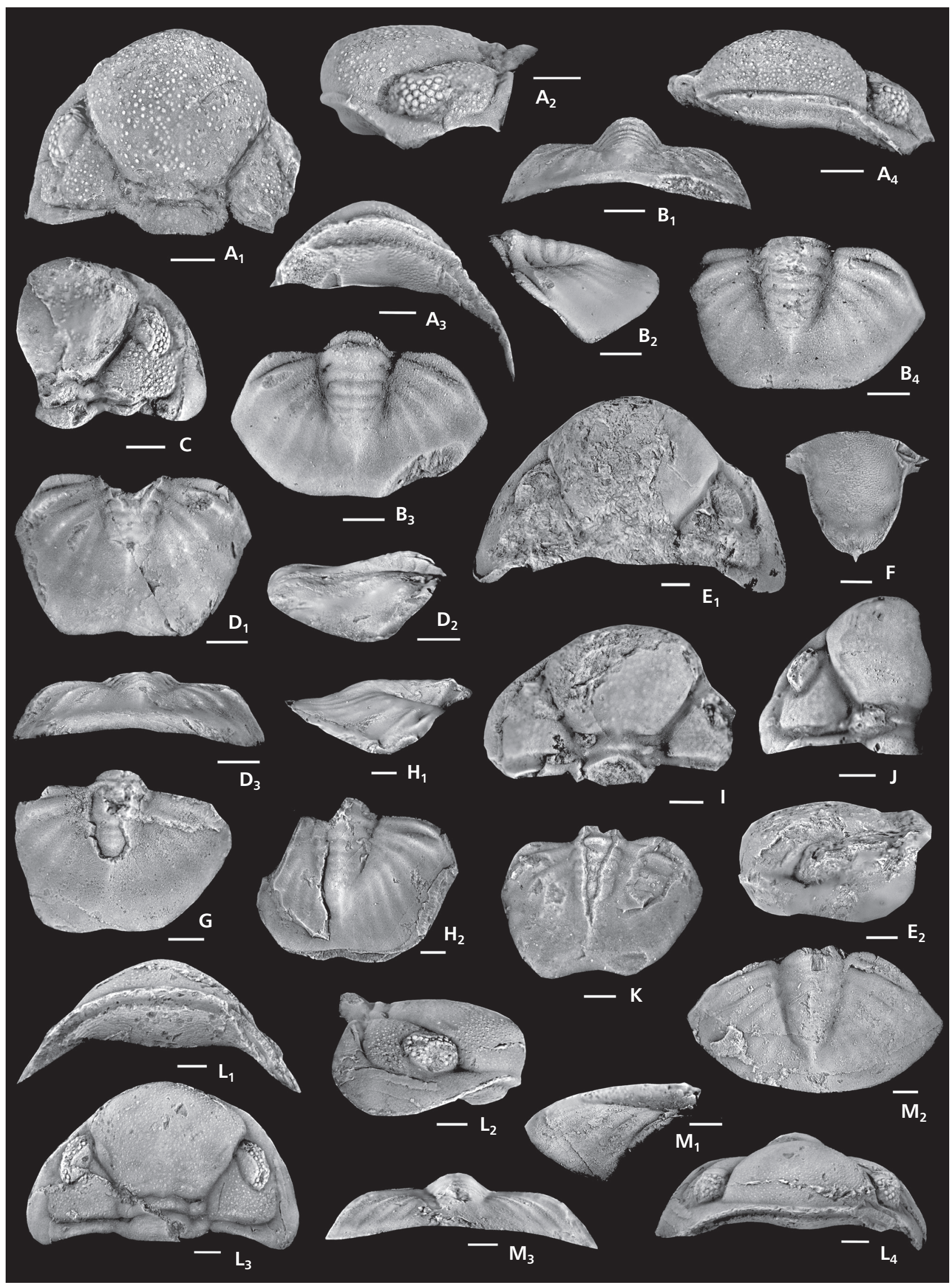


Diagnosis. - Cephalon with gently curved anterior outline, obtusely angled corners of anterior glabellar lobe. Pygidium elongated subtrapezoidal with very short axis, distally straight posterior ribs, wide inflated posterior and posterolateral border, pronounced embayment of posterior margin.

Remarks. - In comparison with the type species the new species has the following distinct features: the cephalon is wider (length $=55 \%$ of width) with gently rounded anterior outline, and an anterior glabellar lobe with a parabolic anterior contour, the axial furrows are less diverging $\left(\right.$ at $\left.60^{\circ}\right)$ until meeting border furrow, where they define the angular corners of glabella. Visual surface of eye lobe is inflated, sloping moderately abaxially, and its distance from posterior border almost equals eye length. Palpebral lobes are without palpebral rim, flat, palpebral furrows very slightly adaxially convex in curvature. Postvincular doublure is three times longer than vincular furrow, with broadly rounded anterior margin (sag.), flat posteriorly. Hypostome (unknown in the type species) is a little longer than wide (without wings) with gently curved hypostomal suture and narrow lateral borders flattening posteriorly. Posterior margin with obvious median spine; additional spines are not evident. Middle body highly vaulted. Middle furrow is distinct, wide, of moderate depth, deepening distally, forming transverse parabolic depression. Posterior lobe of middle body distinctly inflated as far as posterior margin. Sculpture consists of tiny, sometimes fused granules, arranged in backwardlyconvex rows. Pygidium is very long (length/width ratio $=69 \%$ ), with pronounced trapezoidal outline and short anterolateral contour. Pleural margin adaxial to fulcrum approximates length of anterolateral margin. Posterolateral margins straight and converging, very long. Posterior margin as long as posterolateral margin, sigmoidal with pronounced median embayment. Projection of maximum pygidial width crosses fifth axial ring. Axis is very short (sag.), slightly longer than distance between axis and posterior edge of embayment, merging behind with rather long, prominent, thin postaxial ridge. Transverse profile of axis is very low except for first axial ring which is higher than the others. Pleural field with six ribs; posterior pleural bands are thin and distinctly elevated, the first two anterior curved slightly backwards, the remainder straight. Posterolateral and posterior margins with weakly swollen, broad border separated from pleural field by shallow depression. Exoskeleton of pygidium is smooth; posterior pleural bands carry single rows of granules.

\section{Occitanella? sp.}

Figure 6L, M

Remarks. - Single specimens of a well-preserved cephalon (UM-IP 921) and a pygidium (UM-IP 920) were found in dark-red biomicrites of bed CT-S 78 on the eastern slope of Mont Peyroux near Col des Tribes, Frasnian Zone 4 (with Ancyrodella promosica). Their co-occurrence in the same bed, their similar sculpture, and the absence of any other phacopid remains might indicate their conspecificity but this cannot be demonstrated without further material. Their generic assignment is also problematic as the cephalon shares traits of both Occitanella and Chlupacops. The cephalon resembles those of Chlupacops in the short, subtrapezoidal, anterolaterally slightly embayed glabella as well as in the deep and narrow vincular furrow. It is distinct mainly in the less advanced eye lobe, the blunt posterior edge of the vincular furrow and the inflated postvincular doublure, features that characterise Occitanella. By contrast, the pygidium found associated with the cephalon in the same bed differs clearly from Chlupacops in its extended length, the short, slender, posteriorly pointed axis with a long, prominent postaxial ridge, and a wide pleural field with 6 low ribs and faint pleural furrows. In these traits the pygidium is close to the type species of Occitanella. It is distinct by its evenly curved posterior outline and the faint axial rings and pleural ribs. Awaiting additional material, we leave this taxon unnamed and assign it with question to Occitanella.

\section{Genus Chlupacops Feist, 2016 in Feist et al. (2016)}

Type species. - Chlupacops laticeps Feist, 2016 in Feist et al. (2016). Marhouma, Saoura region, north-western Algerian Sahara, Frasnian Zone 5/6.

Diagnosis (emended). - Cephalon wide and short with gently rounded genal angles; glabella very wide anteriorly, with short anterior portion, low transversely, anterolaterally slightly embayed, with steep anterior wall not overhanging in front; sagittally short tripartite intercalating ring; small forwardly-positioned eye with reniform visual surface extending forwards to border furrow or slightly encroaching onto border; divergent, deep, almost straight palpebral furrows, narrow lens-shaped palpebral lobe; cylindrical previncular doublure forming protruding anterior border; continously deep vincular furrow, postvincular doublure long to moderate in sagittal length. Pygidium of high lateral and transverse profile; axis high, with rounded posterior end not reaching posterior margin, with up to eight straight axial rings and deep axial furrows; pleural field with 4-5 vaulted ribs markedly defined by deep pleural furrows that remain distant from postero-lateral margin. Sculpture: dense small-grained tuberculation.

Remarks. - Numerous new taxa from the Montagne Noire exhibit a considerable degree of variability concerning in particular the size of the eye and its visual surface, the 
Table 1. Measurements of ratio parameters, angle of divergence between cephalic axial furrows (corners of anterior glabella - S1), projection of maximum pygidial width in different species of Chlupacops.

\begin{tabular}{|c|c|c|c|c|c|c|c|c|}
\hline Chlupacops & laticeps & cryphoides & $\begin{array}{c}\text { aff. } \\
\text { cryphoides }\end{array}$ & angularis & $\begin{array}{c}\text { clapassou- } \\
\text { sensis }\end{array}$ & migrans & $\begin{array}{l}\text { rectannu- } \\
\quad \text { latus }\end{array}$ & $\begin{array}{c}\text { narbon- } \\
\text { nensis }\end{array}$ \\
\hline \multicolumn{9}{|l|}{ cephalon } \\
\hline length/width & 0.5 & 0.63 & 0.62 & 0.56 & 0.55 & 0.55 & 0.55 & 0.63 \\
\hline \multicolumn{9}{|l|}{ glabella anterior to $\mathrm{S} 1$} \\
\hline length/width & 0.62 & 0.65 & 0.69 & 0.66 & 0.68 & 0.69 & 0.71 & 0.77 \\
\hline length ant. portion/length & 0.45 & 0.42 & 0.42 & 0.41 & 0.42 & 0.39 & 0.4 & 0.41 \\
\hline width/cephalic width & 0.59 & 0.63 & 0.62 & 0.63 & 0.63 & 0.59 & 0.6 & 0.62 \\
\hline angle of divergence & $67^{\circ}$ & $67^{\circ}$ & $66^{\circ}$ & $63^{\circ}$ & $67^{\circ}$ & $61^{\circ}$ & $61^{\circ}$ & $62^{\circ}$ \\
\hline \multicolumn{9}{|l|}{ intercalating ring } \\
\hline length (medially)/width & 0.12 & 0.17 & 0.19 & 0.18 & 0.14 & 0.15 & 0.13 & 0.20 \\
\hline width/width glabella & 0.51 & 0.49 & 0.53 & 0.5 & 0.54 & 0.56 & 0.53 & 0.52 \\
\hline width/width cephalon & 0.31 & 0.33 & 0.33 & 0.33 & 0.34 & 0.35 & 0.32 & 0.32 \\
\hline \multicolumn{9}{|l|}{ visual surface } \\
\hline number of lens rows & $6-7$ & & 11 & 10 & 11 & 13 & 12 & 14 \\
\hline maximum lenses/row & 3 & 4 & 4 & 4 & 4 & $4-5$ & 4 & 5 \\
\hline \multicolumn{9}{|l|}{ postocular field } \\
\hline length/eye-length & 0.9 & 1.18 & 0.67 & 0.63 & 0.61 & 0.42 & 0.46 & 0.42 \\
\hline length/length + eye length & 0.5 & 0.52 & 0.41 & 0.34 & 0.4 & 0.31 & 0.32 & 0.31 \\
\hline \multicolumn{9}{|l|}{ pygidium } \\
\hline length/width & 0.5 & & 0.46 & & 0.47 & 0.48 & 0.49 & 0.47 \\
\hline articulating/anterolat. edge & 0.53 & & 0.5 & & 0.6 & 0.52 & 0.62 & 0.6 \\
\hline \multicolumn{9}{|l|}{ pyg. axis } \\
\hline length/pygidial length & 0.88 & & 0.86 & & 0.89 & 0.81 & 0.89 & 0.77 \\
\hline width/pygidial width & 0.32 & & 0.28 & & 0.28 & 0.33 & 0.31 & 0.31 \\
\hline number of rings & $7+1$ & & $7+1$ & & $8+1$ & $7+1$ & $7+1$ & $7+1$ \\
\hline maximum pygidial width & $6^{\text {th }}$ ring & & $6^{\text {th }}$ ring & & $\begin{array}{c}4^{\text {th }} \text { inter-ring } \\
\text { furrow }\end{array}$ & end of axis & $4^{\text {th }}$ ring & $6^{\text {th }}$ ring \\
\hline
\end{tabular}

degree of its forward extend, the course of the palpebral furrow, generally straight divergent but in some cases slightly convex adaxially or abaxially, and the profile of the anterior face of the glabella which is more or less vaulted but without overhanging the anterior border. In comparison with the type species the new taxa have a shorter anteriormost glabella in front of its maximum width, longer eyes and longer (sag.) more prominent intercalating rings. The original diagnosis is herewith emended to take into account the variability of characters. Variability in the ratio of dimensions, parameters of glabella divergence, number of lens rows, lenses, pygidial axial rings and position of maximum pygidial width are listed in Table 1.

Feist et al. (2016) questionably assigned the Givetian taxa Eocryphops? reichi (Kegel, 1932) and Chotecops? spectabilis (Meischner, 1965) to Chlupacops. According to the emended diagnosis this assignment is no longer followed here. Indeed, unlike reichi, all representatives of Chlupacops have well developed tripartite intercalating rings and eyes reaching the anterolateral border or encroaching onto it. In addition, the visual surface in
Chlupacops specimens are always reniform and composed of at least 15 lenses aligned in several vertical rows, whereas reichi has an elliptic visual surface with only eight lenses which recalls the configuration in Eocryphops as stated by Holloway (2005). The glabella of spectabilis, though similar in outline and profile to representatives of Chlupacops, is narrower (tr.) (56\% of cephalic width vs $59 \%-63 \%$ in Chlupacops), whereas the pygidium has a longer and narrower, posteriorly pointed axis reaching the posterior margin, and more pleural ribs (six versus four). In these features spectabilis is closer to contemporaneous late Chotecops species such as C. koeneni (Holzapfel, 1895) rather than to species of Chlupacops.

Species included. - Chlupacops laticeps Feist in Feist et al., 2016, Marhouma, NW Algerian Sahara, Frasnian Zone 5/6; Ch. cryphoides (Richter \& Richter, 1926), Sessacker, Rhenish Slate Mountain, FZ 12; Ch. aff. cryphoides (Richter \& Richter, 1926) sensu Feist et al. (2016), Marhouma, NW Algerian Sahara, Frasnian Zones 8-10 undifferentiated; Ch. angularis sp. nov., Col du Puech de la Suque, Montagne Noire, middle? Frasnian 
undifferentiated; Ch. clapassousensis sp. nov., Mont Peyroux, Montagne Noire, FZ 8-10 undifferentiated; Ch. migrans sp. nov., La Serre, Montagne Noire, FZ 6; Ch. rectannulatus sp. nov., La Serre, Montagne Noire, FZ 7; Ch. narbonnensis sp. nov., Col du Puech de la Suque, Montagne Noire, FZ 5; Ch. sp. (= Chotecops sp. sensu Helling \& Becker 2012), Seheb-el-Rhassal, Tafilalt, Morocco, FZ 7 C; included with question: $C h$. ? postaltaicus Maximova, 1960 and Ch.? pronini Maximova, 1955 both from latest Frasnian of Rudny Altai and eastern slope of Urals respectively.

Occurrence. - Saoura region, north-western Algerian Sahara, Tafilalt (Morocco), Montagne Noire, Rhenish and Thuringian Slate Mountains.

\section{Chlupacops angularis sp. nov.}

Figure $7 \mathrm{~A}-\mathrm{C}$

Holotype. - Cephalon UM-IP 922, Col du Puech de la Suque, Montagne Noire, middle? Frasnian undifferentiated (Fig. 7A).

Type horizon and locality. - Isolated loose rock of light pink calcilutite in middle? Frasnian of Col du Puech de la Suque section CPS-E (Feist \& Klapper 1985, fig. 5).

Etymology. - Angularis [Lat.] = angular, referring to angular bend of postvincular doublure.

Other material. - Paratypes: fragmentary cephala UM-IP 923-924; additional fragmentary cephalon with eye UM-IP 925a.

Diagnosis. - Cephalon with wide anterolaterally truncated outline, anteromedially prominent composite glabellar lobe with obtusely-angular lateral and traverse anterior profile and very high vertical anterior wall, straight slightly prominent intercalating ring, short occipital ring, vincular furrow bluntly curved medially, postvincular doublure triangular with medially obtusely-angular anterior outline.

Remarks. - The new taxon is only known from internal moulds of its cephalon and as such dimensions might be slightly different according to the external mould. Outline and most dimensions of cephalon and glabella fit diagnostic features of the genus. It is distinct from all other species of Chlupacops mainly by the prominent anterior glabella with very high and vertical anterior wall, forming an obtuse angle with dorsal vault of glabella in lateral view. Glabella bulges medially at junction between dorsal surface and steep anterior wall, and has, in ventral view, an obtusely angular transverse profile (Fig. 7B). In parallel, the anterior and posterior borders of the vincular furrow are bent medially to form obtuse angles without diminishing the length (sag., exsag.) of the vincular furrow. As a result, the postvincular doublure has a triangular outline, which is not seen in any other phacopid. Visual surface carries about 10 rows of lenses, with a maximum of four lenses in a row. Internal mould of exoskeleton exhibits a few spaced tubercles, relicts of external sculpture.

\section{Chlupacops clapassousensis sp. nov.}

Figure 7D-F

1995 Phacops n. sp. a. - Feist, p. 236, fig. 11.6 (USTM-RF 116).

Holotype. - Cephalon UM-IP 925, Clapassous, Montagne Noire, Frasnian Zone 8-10 undifferentiated (Fig. 7D).

Type horizon and locality. - Brown, pink-stained calcilutite, Clapassous, western slope of Puech de la Suque hill, at $1.4 \mathrm{~km}$ SE of Saint-Nazaire-de-Ladarez.

Etymology. - After "Clapassous", western hill slope of Puech de la Suque.

Other material. - Paratypes: cephalon USTM-RF 116, pygidium UM-IP 926; additional material: six cephala and a pygidium UM-IP 927, all from type locality and horizon.

Diagnosis. - Glabella high-vaulted transversely with sigmoidal intercalating ring; small, horizontal palpebral lobes with straight palpebral furrows; pygidium transverse with parabolic posterior outline, axis long with eight axial rings, pleural field of moderate vault with 5 ribs,

Figure 7. All specimens from Montagne Noire, France. - A-C - Chlupacops angularis sp. nov., Col du Puech de la Suque; A - holotype, exfoliated cephalon UM-IP 922, dorsal $\left(A_{1}\right)$, lateral $\left(A_{2}\right)$, anterior $\left(A_{3}\right)$ views; B - exfoliated fragmentary cephalon UM-IP 923, ventral view showing triangular postvincular doublure; $\mathrm{C}$ - exfoliated fragmentary cephalon UM-IP 924, ventral view showing triangular postvincular doublure. $・$ D-F - Chlupacops clapassousensis sp. nov., Clapassous; D - holotype cephalon UM-IP 925, dorsal $\left(D_{1}\right)$, ventral $\left(D_{2}\right)$, anterior $\left(D_{3}\right)$, lateral $\left(D_{4}\right)$ views; E - pygidium UM-IP 926, dorsal $\left(\mathrm{E}_{1}\right)$, lateral $\left(\mathrm{E}_{2}\right)$ views; $\mathrm{F}$ - cephalon USTM-RF 116, dorsal view. $\bullet \mathrm{G}-\mathrm{I}-$ Chlupacops migrans sp. nov., La Serre; $\mathrm{G}-$ cephalon UM-IP 928, dorsal $\left(\mathrm{G}_{1}\right)$, lateral $\left(\mathrm{G}_{2}\right)$ views; $\mathrm{H}$ - holotype cephalon UM-IP 929, dorsal $\left(\mathrm{H}_{1}\right)$, anterior $\left(\mathrm{H}_{2}\right)$, ventral $\left(\mathrm{H}_{3}\right)$ views; I - pygidium UM-IP 930, dorsal $\left(\mathrm{I}_{1}\right)$, lateral $\left(\mathrm{I}_{2}\right)$ views. $・ \mathrm{~J}-\mathrm{M}$ - Chlupacops rectannulatus sp. nov., La Serre; J - pygidium UM-IP 937, dorsal view; K - holotype cephalon UM-IP 934, anterior $\left(\mathrm{K}_{1}\right)$, dorsal $\left(\mathrm{K}_{2}\right)$ views; $\mathrm{L}$ - incomplete cephalon UM-IP 935, dorsal $\left(\mathrm{L}_{1}\right)$, lateral $\left(\mathrm{L}_{2}\right)$ views; $\mathrm{M}$ - cephalon UM-IP 936 , dorsal view. Scale $=1 \mathrm{~mm}$. 


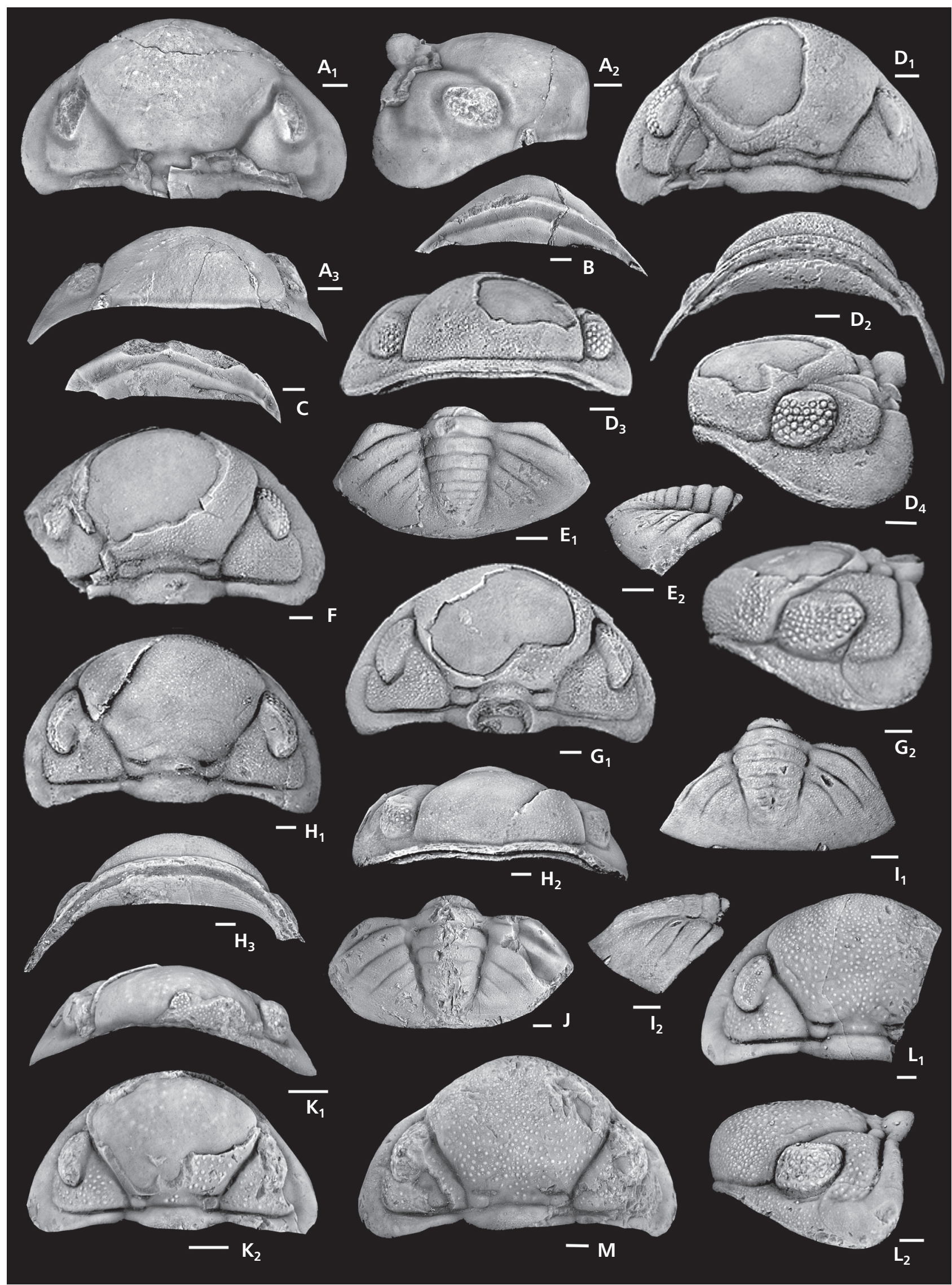


pleural furrows straight, weak interpleural furrows on anterior ribs.

Remarks. - The new species shares the wide angle of divergence of cranidial axial furrows and the configuration of a small eye and lens-shaped palpebral lobes with $C h$. laticeps and cryphoides. Comparatively the other species of the genus have a smaller angle of divergence, longer eyes and wider, slightly crescent-shaped palpebral lobes. The main features that characterise clapassousensis concerne the shape and dimensions of the intercalating ring. It is distinct from the other species by its sigmoidal outline; it is a little longer (sag.) than in laticeps and rectannulatus but markedly shorter than in the other species, hardly tripartite with slightly forwardly curved median lobe, poorly inflated and poorly separated from small trapezoidal lateral lobes. S1 is markedly sigmoidal, continously impressed, deeply abaxially, slightly shallower medially. Other particular cephalic features are as follows: Occipital ring twice length of intercalating ring (sag.), slightly flattened medially, notched behind apodemal pits defining hints of partial lateral occipital lobes. Facial suture poorly impressed, meeting subocular groove shortly behind the junction of the latter with border furrow. Postvincular doublure with blunt anterior edge, flat, a little higher than posterior edge of previncular doublure. The pygidium is close to the type species in overall shape. It is a little longer and has a shorter oblique anterolateral edge. The axis has more axial rings, the pleural field 4-5 weakly vaulted pleural ribs, the anterieurs with perceptible interpleural furrows. Sculpture: uniforme very dense fine granules throughout, a few tubercles on median lobe of intercalating ring, postvincular doublure with fine granules and wavy discontinuous terrace ridges.

\section{Chlupacops migrans sp. nov.}

Figure 7G-I

partim 1977 Phacops (sg.?) migrans n. sp. - Feist, p. 179, pl. 16, fig. 8 (nomen nudum; non fig. 12 = Chlupacops clapassousensis sp. nov.).

Holotype. - Cephalon UM-IP 929, La Serre, Montagne Noire, Frasnian Zone 6 (Fig. 7H).

Type horizon and locality. - Grey-brown trilobite biomicrite, Serre Formation, lower member (Feist 1985); La Serre hill, trench A’48, Frasnian Zone 6 (Feist \& Klapper 1985).

Etymology. - migrans $[$ Lat.] $=$ migrating, after the forward move of the eye.

Other material. - Paratypes: cephalon UM-IP 928, pygidium UM-IP 930; additional material: five cephala UM-IP
931, two pygidia UM-IP 932, all from type locality and horizon; cephalon UM-IP 933 from Clapassous.

Diagnosis. - Anterior glabella low and short anteriorly to maximum width, laterally embayed; axial furrows inward-curved; intercalating ring markedly tripartite with inflated lobes, median lobe ovoid, protruding; S1 curved forward and very shallow medially, long eye lobes; pygidium subtrapezoidal, truncated behind with very long anterolateral edge and backwardly positioned maximum width, wide and short axis, strongly backwardly curved pleural furrows.

Remarks. - The most distinctive trait of the cephalon is the sigmoidal course of the axial furrows. They are inwardly curved between $\mathrm{S} 1$ and the junction of the palpebral furrow, followed anteriorly by the embayment adaxially to the anterior end of the eye lobes before reaching the glabellar corners. These features undergo considerable variation within the population associated in the same bed. The sigmoidal curvature of the axial furrows is extreme in the figured specimen (Fig. 7G), whereas in other specimens of the same size, such as the holotype, the embayment, though present, is much less marked. Instability in the course of the palpebral furrows is also obvious. In most cases these are slightly curved but, as in the holotype, curved on the left side and straight on the right (Fig. $\left.7 \mathrm{H}_{1}\right)$. Other particular features concern the intercalating ring and the eye-complex. S1 sigmoidal, deep and straight or slightly forwardly directed abaxially, much shallower and thinner medially. Intercalating ring is straight slightly forwards-enlarged medially, markedly tripartite, with inflated median lobe, elevated as high as base of anterior glabellar lobe in lateral view, separated from lower, inflated, subtriangular to subquadrangular lateral lobes. Occipital ring is evenly rounded in lateral profile, devoid of lateral occipital lobes. The eye lobe, similar to narbonnensis, has the longest extent (exsag.) among species of Chlupacops. Subocular groove deeply marked posteriorly, merges with anteriormost genal field before reaching anterolateral border furrow. Facial suture is impressed, meeting subocular groove adaxially far behind the junction of the latter with border furrow, defining a depressed triangular area on librigena between subocular groove and lateral border furrow. Sculpture: fine granules of various sizes throughout, postvincular doublure with wavy discontinuous rows of fused granules. The pygidium is dissimilar to the other species by its outline, the wider axis and the strong curvature of pleural furrows. The axis is moderately high, with posterior end slightly higher than postaxial region, remaining markedly distant from posterior edge. Axial furrows moderately converge backward, slightly less so behind second axial ring, fading away around posterior tip. Axial rings are 
straight and low, inter-ring furrows slightly sigmoidal, shallow, the first four reaching axial furrows. Hints of pseudoarticulating half rings are perceptible on axial rings 2 to 4 . Pleural region moderately and evenly vaulted with deep, backwardly curved pleural furrows that die out beyond inner two-thirds of pleural region. Weakly impressed interpleural furrows are discernible on anterior three ribs.

\section{Chlupacops rectannulatus sp. nov.} Figure $7 \mathrm{~J}-\mathrm{M}$

Holotype. - Cephalon UM-IP 934, La Serre, Frasnian Zone 7 (Fig. 7K).

Type horizon and locality. - Light-grey trilobite biomicrite, Serre Formation, lower member (Feist 1985); La Serre hill, trench A'60, Frasnian Zone 7 (Feist \& Klapper 1985; Klapper 1989, pl. 3, figs 3, 4).

Etymology. - Rectannulatus $[$ Lat.] $=$ with straight (intercalating) ring.

Other material. - Paratypes: cephala UM-IP 935-936, pygidium UM-IP 937; additional material: three cephala UM-IP 938, two pygidia UM-IP 939; all from type locality and horizon.

Diagnosis. - Cephalon gently vaulted transversely, with low anterior glabella, medially interrupted straight S1 furrows; very short straight intercalating ring with small inflated lateral lobes; short occipital ring slightly projecting backwards; pygidium sub-hexagonal with truncated posterior and posterolateral outline, almost as long as half width, with short anterolateral edge, long axis; sculpture of spaced granules.

Remarks. - The new species shares with Ch. clapassousensis the very short and wide intercalating ring. It is distinct in having a straight configuration, similar to the type species, with a rectangular median lobe that remains below base of anterior glabellar lobe. In contrast, the S1 furrows are straight and thin abaxially, interrupted and almost effaced medially. The median lobe is uninflated and poorly separated from low lateral lobes, the occipital furrow transverse and only slightly set back behind lateral lobes, the occipital ring narrow, moderately vaulted and backwards projected, the posterior border furrow deeper than lateral border furrow.

The pygidium is distinct from all other species in its subhexagonal, posteriorly and posterolaterally slightly truncated outline, and the advanced position of maximum width. The axis is long and high, defined by axial furrows that converge moderately backwards adjacent to anterior three axial rings, less so thereafter and shallowing around obtusely rounded posterior tip. There are six straight, low, axial rings besides long end piece. Anterior inter-ring furrows are straight, others slightly sigmoidal, shallow medially, the first three reaching axial furrows. Hints of pseudo-articulating half-rings appear on rings 2-4. Postaxial field is very short. Pleural region is moderately vaulted, with weakly vaulted pleural ribs, defined by deep, almost straight pleural furrows that die out beyond inner two-thirds of pleural region. Interpleural furrows are indistinguishable. Particular sculpture of cephalon: drop-like, spaced tubercles, fine granules on occipital ring, posterior border and in genal angle; very fine, dense granulation on pygidium.

\section{Chlupacops narbonnensis sp. nov.}

Figure 8A-F

Holotype. - Cephalon UM-IP 940, Col du Puech de la Suque, Montagne Noire, Frasnian Zone 5 (Fig. 8B).

Type horizon and locality. - Pink-grey crinoidal biomicrosparite, Col du Puech de la Suque, section CPS-E, bed 60, Frasnian Zone 5.

Etymology. - Narbonnensis [Lat.] $=$ from the region of Narbonne.

Other material. - Paratypes: cephala UM-IP 941-943, pygidia UM-IP 944-945; additional material: nine cephala UM-IP 946, two pygidia UM-IP 947; all from type locality and horizon.

Diagnosis. - Cephalon long with narrow parabolic outline; glabella obtusely pointed anteriorly, long in front of $\mathrm{S} 1$; intercalating ring narrow, with inflated lateral lobes; high visual surface with 14 vertical rows of up to five lenses in a row; eye lobe encroaching onto lateral border, pygidium subtrapezoidal, axis remaining markedly distant from posterior margin, axial furrows of low convergence posteriorly, posterolateral edge framed with rim.

Remarks. - In comparison with the other species of Chlupacops, C. narbonnensis has the highest length/width ratios of the cephalon, the anterior glabella lobe and the intercalating ring. As such the cephalon is narrowparabolic in outline and has a relatively narrow (tr.) intercalating ring. Consequently, the axial furrows have a relatively low angle of divergence. The anterior contour of the glabella is obtusely pointed, a feature that is attenuated in larger holaspides but does not occur in the other species. Small holaspid specimens are characterised by a relatively narrow anteriorly pointed glabella and deep outwardly-curved palpebral furrows. These features weaken in larger morphs. In addition, C. narbonnensis has 
the highest number of vertical lens rows and lenses and the shortest postocular field. The intercalating ring is slightly curved transversely, markedly tripartite with inflated, subquadrangular lateral lobes separated from low median lobe by continuous exsagittal furrows. S1 is transverse, deep and straight abaxially, forwardly curved and shallow medially. Occipital furrow is continuously deep, gently curved forwards medially. Occipital ring is long (twice length of intercalating ring [sag.]) with anterior edge notched distally to define weak lateral occipital lobes. Similar to the type species, the eye lobe encroaches on the lateral border. The new species has a rather long (sag.) postvincular doublure that is likewise developed in Ch. laticeps, but is much shorter in all other species. Sculpture: small, spaced tubercles on dorsal surface; postvincular doublure with wavy, discontinous terrace ridges. Pygidium shares with migrans the subtrapezoidal outline, but has a shorter anterolateral edge with a more advanced level of maximum width. It is particular in having a rather short axis remaining markedly distant from the posterior edge. Lateral and posterior margins are framed with thin rim. Axial furrows are deep, converging stronger backwards anteriorly than posterior to $4^{\text {th }}$ axial ring, not united posteriorly. Axial rings very low, straight, provided with pseudo-articulating half-rings. Interring furrows are straight, the anterior four reaching axial furrows. Pleural region moderately vaulted, with 5 moderately vaulted pleural ribs, defined by deep, scarcely curved pleural furrows that die out beyond inner two-thirds of pleural region. Interpleural furrows are discernible in anterior three ribs. Sculpture: very fine, spaced granules on adaxial parts of exoskeleton, distal parts of pleural fields smooth.

\section{Genus Girardina gen. nov}

Type species. - Girardina konradbartzschi sp. nov.

Etymology. - Dedicated to Catherine Girard for her outstanding research on Late Devonian conodonts in the Montagne Noire.

Diagnosis. - Cephalon of widely parabolic outline, gla- bella anteriorly high without overhang, very small eye lobe situated far anteriorly, low, with three aligned lenses, faint vincular furrow, long pygidium with slender axis remaining far from posterior margin, straight axial rings, marked axial furrows with posterior closure, pleural field with faint ribs and pleural furrows reaching posterolateral margin. Sculpture granulose.

Remarks. - The new genus shares with the slightly younger Trimerocephaloides Feist et al. (2009), from the Canning Basin area of NW Australia, reduction of the eye lobe and vincular furrow, long pygidium with axis remaining distant from posterior margin, low relief of pleural ribs and weak furrows. The Australian taxon, however, has an anteriorly low preoccipital glabella with gently sloping profile, no functional visual organ and abaxially deep vincular furrows. In addition, unlike Girardina, the tip of the pygidial axis is connected to a long, prominent postaxial ridge. Similarities between the new genus and the early Famennian Dienstina Richter \& Richter, 1931 from the Rhenish Massif concern the short glabella anteriorly to intercalating ring, the small triangular eye lobe, the reduction of the vincular furrow, the short pygidial axis and the low convexity of the pleural field. Girardina has a more differentiated intercalating ring, a much higher anterior glabella and only three ocular lenses versus $35-40$ in Dienstina. In addition, the pygidium of Girardina is much longer and has a narrower axis.

Occurrence. - Late Frasnian Zone 12 (Thuringia: Kahlleite; Montagne Noire: Causses-et-Veyran).

Species included. - Girardina konradbartzschi sp. nov., G. consimilis sp. nov.; included with question: G.? liopyga (Richter, 1863).

Girardina konradbartzschi sp. nov. Figure $8 \mathrm{G}-\mathrm{K}$

Holotype. - Cephalon UM-IP 948, Kahlleite (Thuringia), Frasnian Zone 12 (Fig. 8I).

Type horizon and locality. - Kahlleite quarry, light grey-

Figure 8. Specimens from Montagne Noire, France, except in G-K. • A-F - Chlupacops narbonnensis sp. nov., Col du Puech de la Suque; A - cephalon UM-IP 941, dorsal $\left(A_{1}\right)$, anterior $\left(A_{2}\right)$ views; B - holotype cephalon UM-IP 940, dorsal $\left(B_{1}\right)$, lateral $\left(B_{2}\right)$ views; C - cephalon UM-IP 942, dorsal view; D - pygidium UM-IP 944, dorsal view; E - pygidium UM-IP 945, dorsal view; F - cephalon UM-UP 943, ventral view. • G-K Girardina konradbartzschi sp. nov., Kahlleite Quarry, Thuringia, Germany; G - hypostome UM-IP 951, internal mould, ventral view; H - fragmentary cephalon UM-IP 949, dorsal $\left(\mathrm{H}_{1}\right)$, lateral $\left(\mathrm{H}_{2}\right)$, ventral $\left(\mathrm{H}_{3}\right)$ views; I - holotype cephalon UM-IP 948, partially exfoliated, anterior $\left(\mathrm{I}_{1}\right)$, dorsal $\left(\mathrm{I}_{2}\right)$ views; $\mathrm{J}$ - exfoliated cephalon UM-IP 950, anteroventral $\left(\mathrm{J}_{1}\right)$, dorsal $\left(\mathrm{J}_{2}\right)$ views; $\mathrm{K}$ - pygidium UM-IP 952, exfoliated, lateral $\left(\mathrm{K}_{1}\right)$, dorsal $\left(\mathrm{K}_{2}\right)$ views. $\bullet \mathrm{L}-\mathrm{R}-$ Girardina consimilis sp. nov., Causses-et-Veyran; $\mathrm{L}$ - fragmentary cephalon UM-IP 956, ventral $\left(\mathrm{L}_{1}\right)$, dorsal $\left(\mathrm{L}_{2}\right)$, lateral $\left(\mathrm{L}_{3}\right)$ views; $\mathrm{M}$ - fragmentary pygidium UM-IP 960, cast of external mould, lateral $\left(\mathrm{M}_{1}\right)$, dorsal $\left(\mathrm{M}_{2}\right)$ views; $\mathrm{N}$ - fragmentary cephalon UM-IP 957, ventral $\left(\mathrm{N}_{1}\right)$, dorsal $\left(\mathrm{N}_{2}\right)$ views; $\mathrm{O}$ - holotype fragmentary cephalon UM-IP 955, dorsal view; P - fragmentary pygidium with relicts of two thoracic segments UM-IP 961, dorsal view; Q - incomplete cephalon UM-IP 858, cast of external mould, dorsal view; R - thoracic segment UM-IP 959, dorsal view. Scale $=1 \mathrm{~mm}$. 


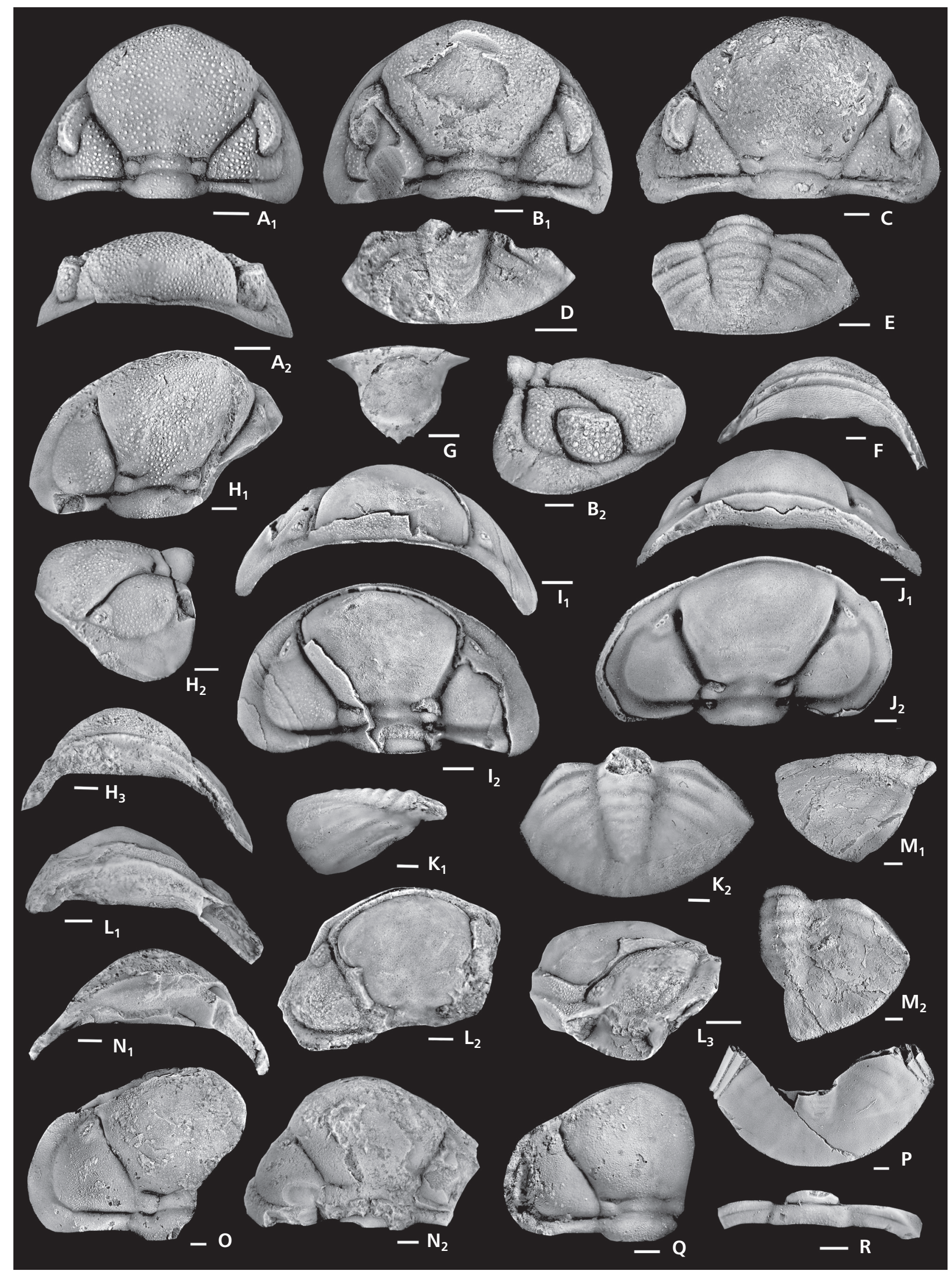


beige ostracod-rich, pyritic biodetrital calcilutite, "Ostracod-limestone" (Bartzsch et al. 1993), "Usseln Kalk" (Gereke 2007, pp. 72, 73).

Etymology. - After Konrad Bartzsch, Saalfeld, for his expert guidance in the field.

Other material. - Paratypes: cephala UM-IP 949-950, hypostome UM-IP 951, pygidium UM-IP 952; additional material: nine cephala (UM-IP 953), seven pygidia (UM-IP 954); all from type locality and horizon.

Diagnosis. - Cephalon with narrow genae, glabella with evenly curved anterior outline and obtusely rounded anterolateral angles, posterior borders adaxially shortening, pleural field of pygidium with distinct ribs and pleural furrows, medium-sized granular sculpture on adaxial parts of cephalon, pygidium smooth.

Description. - Cephalon of widely parabolic outline has a length/width ratio of 0.57 , and an evenly arched transverse profile in anterior view. Its maximum width lies at level of intercalating ring. Glabella not protruding anteriorly; its anterior lobe in front of the intercalating ring has a length/width ratio of 0.72 and its length is $70 \%$ of cephalic length. It is of high transverse vault, with gently curved profile in lateral view except for strongly downcurved frontal face which is almost vertical, without overhang. Axial furrows are deep, straight between S1 and palpebral furrow subtending an angle of $64^{\circ}$, gently curved inwards anteriorly, and forming obtuse glabellar angles. Short, convex-forward S2 and S3 are discernible on internal mould. Narrow rim-like anterior border protrudes slightly. S1 is sigmoidal, continuous on internal mould, interrupted medially on external mould, with deep, slightly oblique apodemal pits that meet axial furrows. Intercalating ring long (sag.), equal to $35 \%$ of cephalic width and $61 \%$ of glabellar width. It is tripartite, with large, trapezoidal, moderately inflated lateral lobes and medially slightly swollen median lobe that merges anteriorly with base of anterior glabella on external mould, being separated from it by shallow, forwardlycurved S1 on internal mould. Occipital furrow evenly curved forwards medially. Occipital ring inflated, higher than base of anterior glabella, twice as long and of same transverse width as intercalating ring, markedly narrowing distally, without lateral lobes. Genal field is inflated, semielliptical, widest opposite $\mathrm{S} 1$, transverse width $=$ $68 \%$ of intercalating ring, surrounded by gently curved lateral and posterior border furrows of even depth. Eye lobe is situated at anterior extremity of genal field, very small, subtriangular, low, and delimited by anterolateral border furrow. Palpebral furrow is very weakly impressed, continuously surrounding eye lobe between axial and border furrows. Visual surface is ill-defined carrying three prominent lenses aligned in an oblique row. Facial suture curves across anterolateral border to embrace ocular lenses before joining lateral border furrow; point $\omega$ is situated far forwards opposite posterior end of eye-lobe, thus defining a very short librigena. Posterior border, narrow at junction with occipital ring, considerably widens abaxially to merge without angle with lateral border. Borders inflated. Vincular furrow is barely discernible on external mould (i.e. Fig. $8 \mathrm{H}_{3}$ ), narrow and weak on internal mould (i.e. Fig. $8 \mathrm{~J}_{1}$ ). Doublure is long (sag.), moderately vaulted, slightly sigmoidal in sagittal profile with gently curved hypostomal suture. Dorsal surface of cephalon with sculpture of medium-sized tubercles on adaxial parts, diminishing in size abaxially, lateral borders smooth; doublure with short, irregular wrinkles. Hypostome is as long as wide (without wings), with wide, evenly curved hypostomal suture; middle body uniformly vaulted, undifferentiated, rather wide (tr.) posteriorly; narrow lateral border and posteriorly extended triangular posterior border with three spines. Pygidium is long (length to width ratio $=0.6$ ), of evenly rounded posterior outline, widest at level of fifth axial ring, with width of anterior articulating edge equal to $37 \%$ that of anterolateral edge, moderately and evenly vaulted in lateral and posterior views. Axis is slender with seven low axial rings besides end piece, obtusely pointed behind, not reaching posterior margin, and slightly curved in lateral view, merging with postaxial area. Axial furrows straight with closure around tip of axis. Inter-ring furrows straight and continuous, almost effaced on exterior of exoskeleton. Pleural field moderately vaulted with 5-6 flat ribs of which anterior two are more strongly vaulted, scarcely narrowing abaxially, backwardly curved distally to reach edge of posterolateral border. First pleural furrows are deep, remainder diminishing progressively rearwards but remain discernible until edges on internal mould, fading away on exterior of exoskeleton. No sculpture discernible on external mould.

Remarks. - Most individual sclerites are tectonically slightly distorted. Depending on preservation, features are different in their relief and outline on internal moulds and on the external surface, especially in the pygidium.

\section{Girardina consimilis sp. nov.}

Figure 8L-R

Holotype. - Cephalon UM-IP 955, Causses-et-Veyran, Montagne Noire, Frasnian Zone 12 (Fig. 8O).

Type horizon and locality. - Brick-red biomicritic cephalopod limestone below Lower Kellwasser horizon, near section CV-S at $1 \mathrm{~km} \mathrm{NW}$ of Causses-et-Veyran village $\left(43^{\circ} 28^{\prime} 46.26^{\prime \prime} \mathrm{N}, 5^{\circ} 94^{\prime} 44.32^{\prime \prime} \mathrm{E}\right)$. 
Etymology. - Consimilis [Lat.], very similar (to type species).

Other material. - Paratypes: cephala UM-IP 956-958, thoracic segment UM-IP 959, pygidia UM-IP 960-961, all from type locality and horizon.

Diagnosis. - Cephalon with broad genal fields, glabella with slightly pointed anterior contour and anterolateral angles, occipital ring long (exsag.) distally, adaxial parts of posterior border not narrowing, pleural field of pygidium with posteriorly effaced ribs and pleural furrows; dense, uniformly fine-grained granules on entire exoskeleton.

Remarks. - The new taxon from the Montagne Noire is identical with the type species in many aspects. Though the material is fragmentary a few particularly diagnostic features allow comparison with the type species. The preoccipital glabellar lobe of consimilis is anteriorly obtusely rounded and has more pointed and distally slightly extended anterior angles, the anterior course of the axial furrows remaining straight. The occipital ring is only slightly narrowing abaxially. The straight adaxial part of the posterior border does not become narrower proximally. The genal field though similar in vault and outline is much wider (tr.) reaching $78 \%$ of width of intercalating ring. Vincular furrow is perceptible as a long (sag.) rather shallow depression on external mould merging behind with strongly vaulted postvincular doublure. Pleural field of pygidium carries rather faint ribs and inter-rib furrows of which only the four anterior ones are barely perceptible on external surface. Sculpture consists of dense very small granules covering uniformly the entire exoskeleton, besides postvincular doublure with wrinkles. Features of thoracic segments are available for consimilis: the axial ring, devoid of lateral lobes, is wider (tr.) than pleura (1:0.86).

\section{Girardina? liopyga (Richter, 1863)}

1863 Phacops liopyga; Richter, p. 669, pl. 19, figs 4, 5.

1926 Phacopidella? liopyga. - Richter \& Richter, p. 204.

1954 Phacopidella cf. liopyga. - Pfeiffer, p. 48, pl. 3, figs 10,11 , pl. 6, fig. 1.

1959 Phacopidella (Dienstina) liopyga. - Pfeiffer, p. 271, pl. 4 , fig. 6 .

Remarks. - The originals of Richter (1863) being lost (fide Pfeiffer 1959), a neotype of the species was erected by Pfeiffer (1959), collected by him near to the type locality of Laasen. This specimen, a thoraco-pygidium and an inverted cephalon in Salter's position, bears features of Dienstina such as the forward-positioned small and low eye and the short pygidial axis. However, the eye has fewer (5-6, fide Pfeiffer 1959, p. 271) lenses which are not included in an elliptic visual surface, the intercalating ring is much shorter and tripartite, and the pygidium has a longer axis with more rings. In these features the species ressembles Girardina. However the higher number of eye lenses does not correspond to the diagnostic number of lenses that characterises the genus. Awaiting more and better preserved material of liopyga, we assign this species to Girardina with question.

\section{Acknowledgements}

We are greatly indepted to Dieter Weyer (Berlin) and Konrad Bartzsch (Saalfeld) for expert guidance and support in the field and for providing trilobite samples from the Kahlleite quarry. Bernard Orth (Montpellier) is thanked for assistance during field work in Morocco. We thank Stephan Helling (Münster) for sending prints of unpublished materials in his care from Moroccan sections for comparisons. The manuscript profited considerably from the constructive suggestions and critical remarks of the reviewers A. Bignon, A. Van Viersen and the handling editor D. Holloway who thoroughly corrected and improved the text and figures. We are very grateful for their help. We thank the executive editor Zuzana Tasaryova for her conscientious care of the manuscript. This is a contribution of UMR 5554, Montpellier (ISEM 2021-228).

\section{References}

Aboussalam, Z.A. 2003. Das "Taghanic-Event" im höheren Mittel-Devon von West-Europa und Marokko. Münsterische Forschungen zur Geologie und Paläontologie 97, 1-332.

Aboussalam, Z.A. \& Becker, R.T. 2001. Prospects for an upper Givetian substage. Mitteilungen des Museums für Naturkunde Berlin, Geowissenschaftliche Reihe 4, 83-99.

DOI 10.1002/mmng.4860040107

Bartzsch, K., Blumenstengel, H. \& Weyer, D. 1993. Field excursion Saalfeld 31. July-3. August 1993 to the Palaeozoic (Devonian) of Thuringia. 1-60. In Göttingen Meeting of the Sub-commission on Devonian Stratigraphy (SDS/IUGS).

Basse, M. 1998. Trilobiten aus mittlerem Devon des Rhenohercynikums: III. Proetida (3), Phacopida (2), Lichida (Lichoidea, Odontopleuridea) und ergänzende Daten. Palaeontographica A 249(1-6), 1-162.

Basse, M. 2006. Eifel-Trilobiten IV. Proetida (3), Phacopida (3). 305 pp. Edition Goldschneck, Quelle \& Meyer Verlag, Wiebelsheim.

Basse, M. \& Lemke, U. 1996. Trilobiten aus mittlerem Givetium (Mittel-Devon) des nördlichen Rechtsrheinischen Schiefergebirges. Geologie und Paläontologie in Westfalen $46,1-65$.

Bault, V., Crônier, C., Allaire, N. \& Monnet, C. 2021. Trilobite biodiversity trends in the Devonian of North Africa. Palaeogeography, Palaeoclimatology, Palaeoecology 565, 1-15. DOI 10.1016/j.palaeo.2020.110208 
Becker, R.T. 1993. Stratigraphische Gliederung und Ammonoideen-Faunen im Nehdenium (Oberdevon II) von Europa und Nord-Afrika. Courier Forschungsinstitut Senckenberg 155, 1-405.

BeCKer, R.T. \& House, M.R. 2000. Late Givetian and Frasnian ammonoid succession at Bou Tchrafine (Anti Atlas, Southern Morocco), 27-36. In El hassani, A. \& TAhiri, A. (eds) Excursion Guidebook, part I: Tafilalt and Maider. SDS-IGCP 421 Morocco Meeting 1999. Notes et Mémoires du Service Géologique 399, Rabat.

Becker, R.T., Feist, R., Flajs, G., House, M.R. \& Klapper, G. 1989. Frasnian-Famennian extinction events in the Devonian at Coumiac, southern France. Comptes Rendus de l'Académie des Sciences Paris 309, II, 259-266.

Becker, R.T., Marshall, J.E.A. \& Da Silva, A.-C. 2020. The Devonian Period, 733-810. In Gradstein, F.M., OGG, J.G., Schmitz, M.D \& OGG, G.M. (eds) Geologic Time Scale 2020, vol. 2. Elsevier, Amsterdam.

DOI 10.1016/B978-0-12-824360-2.00022-X

Buggisch, W. \& Clausen, C.D. 1972. Conodonten- und Goniatiten-Faunen aus dem oberen Frasnium und unteren Famennium Marokkos (Tafilalt, Antiatlas). Neues Jahrbuch für Geologie und Paläontologie, Abhandlungen 141, 137-167.

Bultynck, P. \& Walliser, O.H. 2000. Emsian to Middle Frasnian sections in the Northern Tafilalt. Notes et Mémoires du Service géologique du Maroc 399, 11-20.

Chluṕ́č, I. 1977. The phacopid trilobites of the Silurian and Devonian of Czechoslovakia. Rozpravy Ústředního ústavu geologického 43, 1-172.

ChlupÁč, I. 1993. Trilobites from the Givetian and Frasnian of the Holy Cross Mountains. Acta Palaeontologica Polonica 37(2-4), 395-406.

Chlupáč, I. 1994. Devonian Trilobites - Evolution and events. Géobios 27(4), 487-505. DOI 10.1016/S0016-6995(09)90029-8

Crônier, C. \& Feist, R. 2000. Evolution et systématique du groupe Cryphops (Phacopinae, Trilobita) du Dévonien supérieur. Senckenbergiana lethaea 79, 501-515. DOI 10.1007/BF03043651

Crônier, C. \& François, A. 2014. Distribution patterns of Upper Devonian phacopid trilobites: paleobiogeographical and paleoenvironmental significance. Palaeogeography, Palaeoclimatology, Palaeoecology 404, 12-23.

DOI 10.1016/j.palaeo.2014.03.037

Crônier, C., Feist, R. \& Auffray, J.-C. 2004. Variation in the eye of Acuticryphops (Phacopina, Trilobita) and its evolutionary significance; a biometric and morphometric approach. Paleobiology 30(3), 471-481.

DOI 10.1666/0094-8373(2004)030<0471:VITEOA >2.0.CO;2

Dartiguenave, G. 1999. Evolution de la biodiversité des trilobites sous contrainte du milieu: exemple du mud-mound du Mont Peyroux (Dévonien moyen, Montagne Noire). 29 pp. Diplôme d'études Approfondies (DEA), Paléontologie, Académie de Montpellier, Université Montpellier II Sciences et Techniques du Languedoc (unpublished).

Eldredge, N. 1972. Systematics and evolution of Phacops rana (Green, 1832) and Phacops iowensis Delo, 1935 (Trilobita) from the Middle Devonian of North America. Bulletin of the American Museum of Natural History 147, 45-115.

FeIst, R. 1976. Systématique, phylogénie et biostratigraphie de quelques Tropidocoryphinae (Trilobita) du Dévonien français. Géobios 9/1, 47-80.

FeIst, R. 1977. Le Siluro-Dévonien du sud-est de la Montagne Noire (Hérault, France) et ses faunes de trilobites. 251 pp. unpublished Ph.D. thesis, Université de Montpellier, France.

Feist, R. 1983. The Devonian of the eastern Montagne Noire (France). Guide book, IUGS, Subcommission on Devonian Stratigraphy. 62 pp. Université de Montpellier.

FeIst, R. 1985. Devonian stratigraphy of the southeastern Montagne Noire (France). Courier Forschungsinstitut Senckenberg 75, 331-352.

FeIst, R. 1990. The Frasnian/Famennian boundary and adjacent strataof theeastern MontagneNoire, France. Guidebook, IUGS, Subcommission on Devonian Stratigraphy. 69 pp. Université de Montpellier.

FeIst, R. 1991. The Late Devonian trilobite crises. Historical Biology 5, 197-214. DOI 10.1080/10292389109380401

FEIST, R. 1995. Effect of paedomorphosis in eye reduction on patterns of evolution and extinction in trilobites, 225-244. In McNamara, K.J. (ed.) Evolutionary change and heterochrony. Wiley, Chichester.

FeIst, R. 2002. The Palaeozoic of the Montagne Noire. Joint IGCP 421 and ECOS VIII Symposium, Guidebook of the Field Excursion. 83 pp. Université de Montpellier.

Feist, R. 2003. Biostratigraphy of Devonian tropidocoryphid trilobites from the Montagne Noire (southern France). Bulletin of Geosciences 78(4), 431-446.

Feist, R. 2019. Post-Kellwasser event recovery and diversification of phacopid trilobites in the early Famennian (Late Devonian). Bulletin of Geosciences 94(1), 1-22. DOI 10.3140/bull.geosci.1727

Feist, R. \& Klapper, G. 1985. Stratigraphy and conodonts in pelagic sequences across the Middle-Upper Devonian boundary, Montagne Noire, France. Palaeontographica, Abteilung A 188(1-3), 1-18.

Feist, R. \& Schindler, E. 1994. Trilobites during the Frasnian Kellwasser Crisis in European Late Devonian cephalopod limestones. Courier Forschungsinstitut Senckenberg 169, 195-223.

Feist, R. \& Talent, J.A. 2000. Devonian trilobites from the Broken River region of northeastern Australia. Records of the Western Australian Museum Supplement 58, 65-80.

Feist, R., McNamara, K.J., Crônier, C. \& Lerosey-Aubril, R. 2009. Patterns of extinction and recovery of phacopid trilobites during the Frasnian-Famennian (Late Devonian) mass extinction event, Canning Basin, Western Australia. Geological Magazine 146(1), 12-33.

DOI 10.1017/S0016756808005335

Feist, R., Mahboubi, A. \& Girard, C. 2016. New Late Devonian phacopid trilobites from Marhouma, SW Algerian Sahara. Bulletin of Geosciences 91(2), 243-259.

DOI 10.3140/bull.geosci.1600

Gereke, M. 2007. Die oberdevonische Kellwasser-Krise in der Beckenfazies von Rhenohercynikum und Saxothuringikum 
(spätes Frasnium/frühestes Famennium, Deutschland). Kölner Forum für Geologie und Paläontologie 17, 1-230.

Girard, C., Klapper, G. \& Feist, R. 2005. Subdivision of the terminal Frasnian linguiformis conodont Zone, revision of the correlative interval of Montagne Noire Zone 13, and discussion of stratigraphically significant associated trilobites, 181-198. In Over, D.J., Morrow, J.R. \& Wignall, P.B. (eds) Understanding Late Devonian and Permian-Triassic biotic events: towards an integrated approach. Elsevier, Amsterdam. DOI 10.1016/S0920-5446(05)80007-X

Hawle, I. \& CoRda, A.J.C. 1847. Prodrom einer Monographie der böhmischen Trilobiten. 176 pp. J.G. Calve'sche Buchhandlung, Prague.

Helling, S. \& Becker, R.T. 2012. New proetid and phacopid trilobites from the middle Frasnian (Upper Devonian) of the Tafilalt (Anti-Atlas, SE Morocco). Conference Paläontologische Gesellschaft, Terra Nostra Abstracts S12, 73.

Hickerson, W.J. 1997. Middle Devonian (Givetian) trilobite clusters from eastern Iowa and northwestern Illinois, 224-246. In Brett, C.E. \& BAird, G.C. (eds) Paleontological events, stratigraphic, ecological and evolutionary implications. Columbia University Press, New York.

Holloway, D.J. 2005. The trilobite genera Eocryphops and Plagiolaria (Phacopidae). Paläontologische Zeitschrift 79(2), 227-239. DOI 10.1007/BF02990186

Holzapfel, E. 1895. Das obere Mitteldevon (Schichten mit Stringocephalus Burtini und Maeneceras terebratum) im Rheinischen Gebirge. Abhandlungen der Preussischen Geologischen Landesanstalt, neue Folge 16, 1-459.

House, M.R. 1985. Correlation of mid-Palaeozoic ammonoid evolutionary events with global sedimentary perturbations. Nature 313, 17-22. DOI 10.1038/313017a0

House, M.R. 2002. Strength, timing, setting and cause of midPalaeozoic extinctions. Palaeogeography, Palaeoclimatology, Palaeoecology 181, 5-25.

DOI 10.1016/S0031-0182(01)00471-0

House, M.R., Kirchgasser, W.T., Price, J.D. \& Wade, G. 1985. Goniatites from Frasnian (Upper Devonian) and adjacent strata of the Montagne Noire. Hercynica 1, 1-21.

Johnson, J.G. 1990. Lower and Middle Devonian brachiopoddominated communities of Nevada, and their position in a biofacies-province-realm model, with a section on revision of Middle Devonian conodont zones, by Klapper, G. \& Johnson, J.G. Journal of Paleontology 64(6), 902-941. DOI 10.1017/S002233600002000X

KAYSER, E. 1889. Ueber einige neue oder wenig bekannte Versteinerungen des rheinischen Devon. Zeitschrift der Deutschen Geologischen Gesellschaft 41, 288-296.

KegeL, W. 1932. Über Trilobiten aus dem pelagischen Unterund Mitteldevon. Jahrbuch der Preussischen Geologischen Landesanstalt und Bergakademie zu Berlin 52, 257-283.

KIRCHgASSER, W.T. 1994. Early morphotypes of Ancyrodella rotundiloba at the Middle-Upper Devonian boundary, Genesee Formation, west-central New York. New York State Museum Bulletin 481, 117-134.
Klapper, G. 1985. Sequence in conodont genus Ancyrodella in Lower asymmetricus Zone (earliest Frasnian, Upper Devonian) of the Montagne Noire, France. Palaeontographica Abteilung A 188, 19-34.

Klapper, G. 1989. The Montagne Noire Frasnian (Upper Devonian) conodont succession, 449-468. In McMillan, N.J., Embry, A.F. \& Glass, D.J. (eds) Devonian of the World. Canadian Society of Petroleum Geologists Memoir 14(III) [imprint 1988].

KLAPPER, G. 1997. Graphic correlation of Frasnian (Upper Devonian) sequences in Montagne Noire, France, and western Canada. Geological Society of America Special Paper 321, 113-129. DOI 10.1130/0-8137-2321-3.113

Klapper, G. 2007. Frasnian (Upper Devonian) conodont succession at Horse Spring and correlative sections, Canning Basin, Western Australia. Journal of Paleontology 81(3), 513-537. DOI 10.1666/05088.1

Klapper, G. 2009. Upper Devonian conodonts in the Canning Basin. Appendix 1, 405-413. In Playford, P.E., Hocking, R.M. \& Cockbain, A.E. (eds) Devonian reef complexes of the Canning Basin, Western Australia. Geological Survey of Western Australia Bulletin 145.

Klapper, G. \& Becker, R.T. 1999. Comparison of Frasnian (Upper Devonian) conodont zonations. Bollettino della Società Paleontologica Italiana 37(2-3), 339-348.

Klapper, G. \& Kirchgasser, W.T. 2016. Frasnian Late Devonian conodont biostratigraphy in New York: graphic correlation and taxonomy. Journal of Paleontology 90(3), 525-554. DOI 10.1017/jpa.2015.70

Klapper, G., Feist, R. \& House, M.R. 1987. Decision on the boundary stratotype for the Middle/Upper Devonian Series boundary. Episodes 10, 97-101.

DOI 10.18814/epiiugs/1987/v10i2/004

Klapper, G., Kirchgasser, W.T. \& Baesemann, J.F. 1995. Graphic correlation of a Frasnian (Upper Devonian) composite standard, 177-184. In MANN, K.O. \& LANE, H.R. (eds) Graphic correlation. SEPM (Society for Sedimentary Geology) Special Publication 53.

DOI 10.2110/pec.95.53.0177

Klapper, G., KuZ’min, A.V. \& Ovnatanova, N.S. 1996. Upper Devonian conodonts from the Timan-Pechora region, Russia, and correlation with a Frasnian composite standard. Journal of Paleontology 70(1), 131-152. DOI 10.1017/S0022336000023179

Klapper, G., Uyeno, T.T., Armstrong, D.K. \& Telford, P.G. 2004. Conodonts of the Williams Island and Long Rapids formations (Upper Devonian, Frasnian-Famennian) of the Onakawana B Drillhole, Moose River Basin, northern Ontario, with a revision of Lower Famennian species. Journal of Paleontology 78(2), 371-387.

DOI 10.1666/0022-3360(2004)078<0371:COTWIA $>2.0 . C O ; 2$

Kralick, J.A. 1994. The conodont genus Ancyrodella in the middle Genesee Formation (lower Upper Devonian, Frasnian), western New York. Journal of Paleontology 68(6), 1384-1395. DOI 10.1017/S0022336000034351

Lerosey-Aubrit, R. \& Feist, R. 2012. Quantitative approach to diversity and decline in Late Palaeozoic trilobites, 535-550. 
In TAlent, J.A. (ed.) Earth and life. Global biodiversity, extinction intervals and biogeographic perturbations through time. Springer, Dordrecht. DOI 10.1007/978-90-481-3428-1_16

McLean, R.A. \& Klapper, G. 1998. Biostratigraphy of Frasnian (Upper Devonian) strata in western Canada, based on conodonts and rugose corals. Bulletin of Canadian Petroleum Geology 46(4), 515-563.

McKellar, R.C. \& Chatterton, B.D.E. 2009. Early and Middle Devonian Phacopidae (Trilobita) of southern Morocco. Palaeontographica Canadiana 28, 1-110.

McNamara, K.J. \& Feist, R. 2016. The effect of environmental changes on the evolution and extinction of Late Devonian trilobites from the northern Canning Basin, Western Australia, 251-271. In Becker, R.T., Königshof, P. \& Brett, C.E. (eds) Devonian climate, sea level and evolutionary events. Geological Society London, Special Publication 423.

DOI 10.1144/SP423.5

Maximova, Z.A. 1955. Trilobity srednogo i verchnego devona Urala i severnykh Mugodzhar. Trudy Vsesoyuznogo Nauchno-Issledovatel'skogo Geologicheskogo Instituta, N.S. 3, $1-264$.

MaXimova, Z.A. 1960. Devonskie i kamennougol'nye trilobity Rudnogo Altaya. Paleontologicheskoe obosnovanie stratigrafii paleozoya Rudnogo Altaya. Vypusk 7. 123 pp. Gosudarstvennoe nauchno-tekhnicheskoe izdatel'stvo, Moscow.

Meischner, D. 1965. Neue Trilobiten aus dem Devon des Kellerwaldes. Fortschritte in der Geologie von Rheinland und Westfalen 9, 119-150.

MüNSTER, G. 1840. Die Versteinerungen des Uebergangskalkes mit Clymenien und Orthoceratiten von Oberfranken. Beiträge zur Petrefakten-Kunde 3(7), 33-121.

Over, D.J., Hopkins, T.H., Brill, A. \& Spaziani, A.L. 2003. Age of the Middlesex Shale (Upper Devonian, Frasnian) in New York State. Courier Forschungsinstitut Senckenberg 242, 217-223.

Pisarzowska, A., Sobstel, M. \& Racki, G. 2006. Conodont-based event stratigraphy of the early-middle Frasnian transition of the south Polish carbonate shelf. Acta Palaeontologica Polonica 51(4), 609-646.

Pisarzowska, A., Becker, R.T., Aboussalam, Z.S., Szczerba, M., Sobien, K., Kremer, B., Owocki, K. \& Racki, G. 2020. Middlesex/punctata Event in the Rhenish Basin (Padberg section, Sauerland, Germany) - geochemical clues to the early-middle Frasnian perturbation of global carbon cycle. Global and Planetary Change 191, 1-14.

DOI 10.1016/j.gloplacha.2020.103211

Pfeiffer, H. 1954. Der Bohlen bei Saalfeld/Thür. Geologie, Beiheft 11, 1-105.

Pfeiffer, H. 1959. Neue Beobachtungen und Funde aus dem Saalfelder Oberdevon. Geologie 8(3), 262-279.

Richter, R. 1863. Aus dem thüringischen Schiefergebirge. Zeitschrift der Deutschen Geologischen Gesellschaft 15, 659-676.

Richter, R. \& Richter, E. 1926. Beiträge zur Kenntnis devonischer Trilobiten. IV. Die Trilobiten des Oberdevons. Abhandlungen der Preussischen Geologischen Landesanstalt, neue Folge 99, 1-314.
RichteR, R. \& Richter, E. 1931. Unterlagen zum Fossilium Catalogus, Trilobitae. V. Senckenbergiana 13, 140-146.

Richter, R. \& Richter, E. 1943. Studien im Paläozoikum der Mittelmeer-Länder. Trilobiten aus dem Devon von Marokko, mit einem Anhang über Arten des Rheinlands. Senckenbergiana 26(1/3), 116-199.

SAlter, J.W. 1864. A monograph of the British trilobites from the Cambrian, Silurian and Devonian formations. Part 1. Monographs of the Palaeontographical Society 16(67), 1-80. DOI 10.1080/02693445.1864.12113212

Sandberg, C.A., Morrow, J.R. \& Ziegler, W. 2002. Late Devonian sea-level changes, catastrophic events, and mass extinctions. Geological Society of America Special Paper 356, 473-487. DOI 10.1130/0-8137-2356-6.473

SmeEnK, Z. 1983. Devonian trilobites of the southern Cantabrian Mountains (northern Spain) with a systematic description of the Asteropyginae. Leidse Geologische Mededelingen 52(2), 383-511.

Stegemann, T. 2005. Taxonomie und Phylogenie von Phacopiden (Trilobita) des höheren Givetiums (Mitteldevon). Münsterische Forschungen zur Geologie und Paläontologie 100, 21-33.

Struve, W. 1990. Paläozoologie III (1986-1990). Courier Forschungsinstitut Senckenberg 127, 251-279.

Stumm, E.C. 1953. Trilobites of the Devonian Traverse Group of Michigan. Contributions from the Museum of Paleontology, University of Michigan 10(6), 101-157.

Termier, H. 1936. Etudes géologiques sur le Maroc central et le Moyen Atlas septentrional. Notes et Mémoires, Service des Mines \& Carte géologique du Maroc 33, 1-1566.

VAn Viersen, A.P. \& Vanherle, W. 2018. The rise and fall of Late Devonian (Frasnian) trilobites from Belgium: taxonomy, biostratigraphy and events. Geologica Belgica 21(1-2), 73-94. DOI $10.20341 / \mathrm{gb} .2018 .005$

WhidBorNe, G.F. 1889. A monograph of the Devonian fauna of the south of England. Vol. 1. The fauna of the limestones of Lummaton, Wolborough, Chircombe Bridge and Chudleigh. Part 1. Monographs of the Palaeontographical Society 42(202), 1-46. DOI 10.1080/02693445.1889.12028005

Whittington, H.B. \& Kelly, S.R.A. 1997. Morphological terms applied to Trilobita, 313-329. In KAESLER, R.L. (ed.) Treatise on invertebrate paleontology. Part O. Arthropoda 1. Trilobita, revised. Volume 1: Introduction, Order Agnostida, Order Redlichiida. Geological Society of America and University of Kansas Press, Boulder, Colorado and Lawrence, Kansas.

Zambito, J.J., Brett, C.E., Baird, G.C. 2012. The Late Middle Devonian (Givetian) Global Taghanic Biocrisis in its type area (northern Appalachian Basin): geologically rapid faunal transitions driven by global and local changes, 677-703. In TAlent, J.A. (ed.) Earth and life. Global bniodiversity, extinction intervals and biogeographic perturbations through time. Springer, Dordrecht. DOI 10.1007/978-90-481-3428-1_22

Ziegler, W. \& Sandberg, C.A. 1990. The Late Devonian Standard Conodont Zonation. Courier Forschungsinstitut Senckenberg 121, 1-115. 